\title{
LAS RENTAS DE ANFION: EL MONOPOLIO ESPAÑOL DEL OPIO EN FILIPINAS (1844-1898) Y SU RECHAZO POR LA ADMINISTRACION NORTEAMERICANA
}

\author{
POR \\ JUAN F. GAMELLA y ELISA MARTIN \\ Facultad de Ciencias Políticas y Sociología. Universidad de Granada
}

\section{INTRODUCCION}

Cuando en 1898 los Estados Unidos arrebataron a España el control de Filipinas, residía en el archipiélago una considerable población china, entre la que estaba muy extendida la costumbre de fumar opio (1). Durante el último medio siglo, la administración española había mantenido un sistema de provisión de opio a los chinos mediante un monopolio estatal, que gestionaban empresarios privados tras ganar el derecho en subasta pública. Ese sistema parece haber cumplido sus tres objetivos fundamentales: evitar que el consumo de opio se extendiese entre los nativos, reducir el contrabando y el mercado negro, y aumentar la contribución de los chinos al erario público. No obstante, a los pocos días de su desembarco en Manila, el mando militar norteamericano puso fin al sistema español, estableció un impuesto sobre la venta del opio y prohibió los fumaderos públicos. En parte como resultado de tal medida, y también a causa de la crisis social y económica que sacudió las islas durante la ocupación militar y la brutal guerra contra los independentistas filipinos (1899-1902), el uso de opio se extendió entre la población indígena de forma tan alarmante que, en 1903, el gobiemo civil norteamericano decidió

SiglaS UTILIZADAS:

AHN: Archivo Histórico Nacional, Madrid.

PNA: Philippine National Archives, Manila.

RAH: Real Academia de la Historia, Madrid.

(1) Anfión, opio, es término tomado del portugués "anfião". Procede del árabe "afiyũn", que, a su vez, deriva del griego "opion". J. CoRominas, Diccionario crítico etimológico de la lengua Castellana. Berna, 1954. Cien mil chinos aproximadamente, según A. S. TAN, The Chinese in the Philippines, 1898-1935: A Study of their National Awakening. Quezon City: Garcia Publishing Co., 1972, pág. 2. 
retornar al sistema español, redactó un proyecto de ley en ese sentido y lo envió a Washington para su ratificación.

Ese proyecto, sin embargo, encontró tal oposición en Filipinas y en Estados Unidos que el presidente Roosevelt hubo de paralizar su aprobación. Se abrió entonces un enconado debate entre la Comisión Filipina, que defendía la medida, y los oponentes de la "legalización», entre los que destacó un grupo de misioneros protestantes. La polémica se zanjó con el nombramiento de un comité de "expertos" que debía estudiar el problema del opio en otros países de Asia y proponer la solución más adecuada a Filipinas. Tras recoger información por todo Oriente, el Comité de la Comisión Filipina redactó un documento muy influyente que sirvió de base para la decisión final del contencioso: la prohibición progresiva del opio en todo el archipiélago, siguiendo el sistema impuesto por los japoneses en Formosa.

El contacto de la administración norteamericana con un problema de uso masivo de opiáceos en su primera experiencia colonial fue un hecho decisivo en la creación del control internacional de "narcóticos», un proyecto que marca una nueva era en la problematización mundial del uso de drogas y en el que Estados Unidos ha sido adalid indiscutible. Es significativo a este respecto que el hombre que más influyó en el diseño de la legislación que se aplicó en Filipinas, el obispo episcopaliano Charles Brent, fuera después presidente de la primera comisión internacional sobre el opio que se reunió en Shangai en 1909 y jefe de la delegación america en la primera conferencia internacional, convocada en La Haya en 1911 (2). En ambas asambleas, en las que se cimentó el sistema prohibicionista internacional que todavía impera, Brent fue el dirigente más influyente del movimiento antiopio (3).

El movimiento por el control internacional de los fármacos psicoactivos creció paralelamente a la hegemonía económica, política y militar de Estados Unidos y, en ese tema, los norteamericanos se esforzaron desde el principio por ofrecer una opción distinta a las potencias coloniales europeas a quienes venían a sustituir. En ese sentido, el choque de sistemas de control público en Filipinas tuvo enormes repercusiones internacionales, especialmente por su conexión con la más importante "crisis de

(2) Los misioneros americanos llevaban varias décadas luchando contra el opio en China. El caso de Fililipinas les permitió, por primera vez, conectar el problema en Asia con el interés inmediato de la política exterior norteamericana.

(3) Véase D. F. Musto. The American Disease: Origins of Narcotics Control. Oxford: Oxford University Press, 1987, pág. 26. 
drogas» contemporánea: la del opio en China, que subyace a más de siglo y medio de transformaciones en Asia, donde el imperio británico actuó en gran manera como un "cártel» en la manufactura y exportación de opio (4).

Los opiáceos representaban también un problema interno para los norteamericanos, tanto por su consumo por amplios sectores de la población, como por la creciente alarma que tal uso provocaba entre poderosos grupos de presión y que conectaba con el movimiento prohibicionista del alcohol. En este sentido, aunque existían algunas leyes estatales restrictivas, fue el esfuerzo por imponer un nuevo orden mundial -ese ejemplo de «altruismo internacional»- el que provocó la introducción de leyes prohibicionistas a nivel federal. De hecho, sólo tras la primera guerra mundial fueron los problemas internos de Estados Unidos prioritarios en el trazado de la legislación y la política norteamericana respecto a las drogas psicoactivas (5). Para entonces, el gobiemo estadounidense había promulgado sucesivas leyes prohibicionistas de índole federal al objeto de cumplir sus compromisos internacionales; la aplicación de dichas leyes afectó desde ese momento la producción y el uso de drogas en todo el planeta.

La compleja historia del triunfo prohibicionista en Estados Unidos y el papel en este proceso de instituciones, movimientos sociopolíticos y uemprendedores morales», se conoce bastante bien gracias a los detallados trabajos de Courtwright, Musto, Taylor, Lowes y Terry, entre otros (6). Sin embargo, el choque de sistemas de control social ocurrido en Filipinas ha pasado desapercibido, por no conocerse bastante el sistema español y por ignorarse que había entre los americanos voces discordantes que hubieron de ceder ante la enorme fuerza de la oposición organizada. Entre esas voces destaca la de William Howard Taft, primer gobernador civil de Filipinas y futuro presidente de Estados Unidos y del Tribunal Supremo.

Nuestro primer objetivo en este estudio es perfilar las características del sistema español, su origen, su funcionamiento y su relación con el creciente papel de los chinos en la economía de la

(4) C. A. TrockI, Opium and Empire. Chinese Society in Colonial Singapore, 1800-1910. Ithaca: N. Y. Cornell University Press, 1990, págs. 50-79.

(5) A. H. TAYLOR, Diplomacy and the Narcotics Traffic, 1900-1939. Durham: N. Y. Duke University Press, 1969, pág. 329

(6) Véanse D. T. CourTwright. Dark Paradise. Londres: Harvard University Press, 1982; Musto, obra citada; Taylor, obra citada; P. D. LowES, The Genesis of International Narcotics Control Ginebra: Librarie Droz, 1966; y C. E. TERRY y M. Pellens. The Opium Problem. Montclair, N. J.: Patterson Smith, 1928. 
colonia española en el siglo XIX. En segundo lugar consideraremos por qué ese régimen no complació a los norteamericanos y estudiaremos los orígenes de la alternativa impuesta por la administración estadounidense. El choque entre ambos sistemas supone una importante disyuntiva respecto al papel del Estado y los regímenes oficiales de control social en el uso no terapéutico de drogas. Muchos de los dilemas que confrontamos hoy día aparecen ya planteados de forma nítida en ese conflicto hace un siglo. Especialmente en lo que se refiere a la elección de la actitud social más conveniente respecto al uso de drogas adictivas de manera que, dentro de un estado de derecho, se limite el uso destructivo que se hace de ellas. Tres parecen ser las principales alternativas: la prohibición de su comercio con la consiguiente criminalización de distribuidores y usuarios, la legalización de los fármacos como objetos de consumo, o la provisión autorizada a aquellos ya habituados a su uso. En Filipinas aparecen ejemplos de los tres métodos y de sus consecuencias, por lo que este caso histórico ofrece importantes intuiciones en un problema hoy esencial: ¿Cuál es el mejor régimen legal para los fármacos psicoactivos?

\section{EL SISTEMA ESPAÑOL}

En la colonia española el uso no terapéutico de opio fue siempre una costumbre circunscrita a la población china. Los chinos de Filipinas provenían en su mayor parte de la región de Fukien, corazón del área fumadora de opio en China desde que arribó allí el hábito desde Formosa en el siglo XVII. Nuestros datos sobre esta costumbre entre los chinos de Filipinas se remontan a 1780 (7), aunque no parece que el fenómeno fuera muy significativo o se le prestase mucha atención hasta 1814, cuando el enérgico gobernador Gardoqui dictó la primera legislación sobre el tema, prohibiendo la importación y venta de opio en el archipiélago. A pesar de la prohibición y sus severas penas (seis años de carcel por contrabando y hasta cuatro años de prisión por consumo (8), muchos chinos siguieron dándose a su afición de fumar

(7) R. M. Zarco "The Philippines Chinese and the Opium Addiction" en The Chinese in the Philippines editado por Félix Alfonso. Manila: Solidaridad Pub. House, 1969, págs. 96-109.

(8) El decreto establecía penas de quince días de arresto por la primera falta, treinta días por la segunda y cuatro años en presidio por la tercera. Se concedió un plazo de ocho días a aquellos que poseyesen opio para que lo depositasen en la aduana al objeto de ser reenviado a China. (Véase el decreto del Intendente de Hacienda de 1 diciembre de 1814, por el que se imponen penas por la introducción, contrabando y uso de anfión. RAH, Indice General de Rodríguez Villa: VII 1). 
opio, buscando la protección de españoles, para lo que «solían alquilar el piso bajo de la casa de alguna persona influyente o privilegiada, cuyas consideraciones les tuvieran al abrigo de las pesquisas de los alcaldes" (9).

En la siguiente década se produjo un giro en la actitud española hacia el opio, sobre todo hacia su elaboración local. No fue ajena a este cambio la percepción de que en la vecina China se había desarrollado un mercado de opio del que los ingleses estaban obteniendo pingües beneficios y del que Filipinas podía también sacar partido (10). Así, varios notables locales defendieron la idea de que Filipinas, más cercana a China que la India, podría producir opio con más beneficio que Bengala. Por ejemplo, Bernáldez y Pizarro, en sus «Reformas en Filipinas» de 1828, urgió el cultivo de la "cebolla de la adormidera blanca», dejando de «renunciar por más tiempo al lucro inmenso que debe resultar de la siembra del Anfión en estas Islas" (11) y negando, por infundados, los temores del gobernador en cuanto a la alteración del orden o a que los nativos pudieran adquirir la costumbre de fumar esa droga. En los diez y siete años que había sido oidor de la audiencia de Manila, argüía Bernáldez, no había conocido ni un sólo caso de intoxicación que hubiera dado lugar a "escándalo de embriaguez o de furia en ninguno de los muchos chinos radicados allí, y que usan comúnmente el Anfión prohibido», y ni un sólo nativo que hubiera sido inculpado por usar opio, al cual,

(9) M. Buzeta y F. Bravo, Diccionario Geográfico, Estadístico, Histórico de la Islas Filipinas. Madrid: José C. de la Peña, 1850, vol. 2, págs. 246.

(10) El negocio de exportación de opio de Bengala y su contrabando a China cambió bruscamente el signo de la balanza de pagos entre China y Gran Bretaña, que se había mantenido secularmente en contra de los británicos. A partir de 1826, en tan sólo siete años, el comercio de opio costó a China plata por valor de 17 millones de dólares. En los años siguientes el saldo se tornó aún más desfavorable para el celeste imperio, de tal manera que, en sólo unas décadas, gran parte de la plata que durante siglos se había acumulado en China abandonó el pais (véase D. E. OWEN. British Opium Policy in China and India. Londres: Archon Books, 1934, págs. 131-32, y M. GrEenBERG. British Trade and the Opening of China, 1800-1842. New York: Monthly Review Press, 1951, págs. 141-42). La pérdida monetaria deterioró la ya delicada situación sociopolítica del imperio, empobreciendo a las multitudes campesinas que pagaban sus impuestos en plata y trastocando el orden económico de provincias enteras (véase E. Wolf. Europe and the People Without History. Berkeley: University of California Press, 1982, págs. 257-58; F. Wakeman. Strangers at the Gate: Social Disorder in South China, 1839-1861. Berkeley: University of California Press, 1975, pág. 126.

(11) En los "Estudios en el Archivo General de Indias de Sevilla", publicados por los Anales de la Real Academia de Farmacia (1953), hay una copia de la carta que el Ministerio de Ultramar envía al Superintendente de hacienda en Filipinas con el texto de la orden sobre la "siembra y exportación del Anfión", y un resumen de las conclusiones de Bernáldez. Pizarro respecto a las ventajas de tal negocio. 
sin excepción «miran los Indios con la mayor indiferencia y desprecio" (12).

Esas sugerencias encontraron oídos favorables en España y una real ordenanza de 6 de abril de 1828 permitió el cultivo de opio en Filipinas para su exportación (13). La nueva medida formaba parte de los esfuerzos por desarrollar la economía filipina. España, no lo olvidemos, había ya perdido casi todas sus colonias en América y el comercio del Galeón había cesado definitivamente en 1815. Sin embargo, a pesar de la legislación favorable, el cultivo de opio no prosperó nunca en las islas. Quizá las regulaciones resultaron excesivas, pues el suelo y el clima de las provincias cercanas a Manila, donde se limitó el cultivo, no eran favorables. No obstante, la idea de favorecer el opio como cultivo de exportación siguió viva en la mente de muchos reformadores. Aún en 1895 Montero y Vidal seguía insistiendo en los "considerabilísimos beneficios» que podría reportar a la colonia un mayor cultivo de la "amapola blanca» para «exportación a China... de su producto narcótico», "dejándonos de quijotismos», como el del general Norzagaray que informó en contra de tal cultivo en 1858 por urazones de moral y de salud pública» (14).

Durante esas décadas, la producción local del opio se encaminaba al mercado exterior, sobre todo a China; pero se seguía percibiendo negativamente el uso local, cuya prohibición se mantuvo. Sabemos, sin embargo, que los chinos en Filipinas continuaron fumando opio, que entraba en las islas de contrabando. Muestra de dicho contrabando y del esfuerzo por combatirlo es, por ejemplo, el expediente de 1836 que describe la causa contra Baltasar Mier y Manuel Romero por «la introducción fraudulenta de una caja de anfión" que costó a Romero la suspensión de la alcaldía mayor de Cebú (15).

Tras la guerra del opio y el tratado de Nanking de 1842, la nueva situación internacional en Extremo Oriente produjo un cambio de actitud oficial española en el tema del opio y en muchos otros. Se abrió entonces un debate respecto a la viabilidad de usar tal producto como otra fuente de ingresos guberna-

(12) M. BERnÁldez y PizarRo. "Memoria presentada sobre posibles reformas en Filipinas" AGI, Ultramar, leg. 663. 1827, págs. 251-52.

(13) Anales de la Real Academia de Farmacia. 1953, pág. 167.

(14) J. MonTERo y Vidal. Historia general de las Filipinas, desde el descubrimiento de dichas islas hasta nuestros dias. Madrid: Viuda e hijos de Tello, 1895, vol. 3, pág. 64 .

(15) AHN Ultramar, legajo 1.254, no 83. 
mental. Como veremos más adelante, tal debate se relaciona con el nuevo papel de los chinos en la colonia.

En 1843 se nombró una comisión oficial para estudiar la posibilidad de que le fuera permitido el consumo de opio a los chinos de Filipinas, bajo el control monopolístico del estado. La comisión informó favorablemente y en diciembre de ese mismo año se dictó un bando por el que se «autorizaba y reglamentaba el uso de anfión por los chinos, declarándolo ramo estancado", es decir, monopolio estatal (16). Esta innovación formaba parte de un conjunto de medidas liberalizadoras tomadas durante el gobierno de Espartero, que coincidían con una delicada situación en Filipinas, cuando los chinos alcanzaron un mínimo demográfico y los mestizos acapararon el comercio local en la mayor parte de las provincias, lo que causó una considerable alza de precios (17).

No hubo decisivas discrepancias entre liberales y conservadores respecto a la legalización, pues seis años después, en pleno decenio conservador en la Península, otra comisión revisó la cuestión, abriendo un importante debate sobre la pertinencia de continuar con la legalización del anfión y aumentar la producción local (18). La comisión solicitó el consejo del catalán Sinibaldo de Mas, un interesante personaje que conocía de primera mano todo Oriente y que era probablemente el principal sinólogo español del momento. Mas respondió que por su propia experiencia conocía que el opio no era más tóxico ni perjudicial que el tabaco o el alcohol y que, por lo que él había observado en el continente, los chinos que fumaban opio trabajaban tanto o más que los abstemios.

Con estos argumentos a su favor, la comisión aconsejó a favor de la legalización, aduciendo las siguientes razones:

1. No se conocía a ciencia cierta que el opio causase daño físico y, en cualquier caso, no sería mayor que el que causaban el tabaco o el alcohol.

2. La prohibición no sería respetada por la población china de Filipinas. Su imposición sólo daría como fruto un

(16) MonTERo, [14], vol. 3. pág. 63.

(17) E. B. WiCKBERG. "The Chinese Mestizo in Philippine History" Journal of Southeast Asian History. 1964, vol. 5 (1), págs. 62-100.

(18) El debate formaba parte de un esfuerzo general por desarrollar la agricultura filipina, $y$ parte de sus resultados aparecieron en un informe que en abril de 1849 presento la Sociedad Económica de Amigos del País, tratando del cultivo de la amapola blanca y la preparación de opio en Filipinas. 
aumento de los delitos, y una necesidad mayor de gastos en justicia y policía. La experiencia demostraba que el contrabando era imposible de evitar en un archipiélago de siete mil islas.

3. El monopolio podía aportar ingresos para el erario público, con lo que el control del uso del opio pasaría de ser un gravamen a ser un beneficio.

4. Perseguir a los chinos en Filipinas por su uso de anfión perjudicaría las relaciones españolas con el Celeste Imperio, cada vez más importantes comercialmente para la colonia.

Basándose en tales razones, el gobierno español decidió continuar con el "ramo estancado" del anfión, que se mantendría hasta el final de su dominio en el archipiélago. A partir de entonces, el del opio fue uno de los monopolios más lucrativos de la colonia, siguiendo, en su filosofía impositiva, las líneas de ciertos impuestos municipales y provinciales existentes desde principios de siglo, tales como los de mercados, pesas y medidas, los de mataderos, los de transportes, etc. En sus detalles parece haberse inspirado en el sistema impuesto por los ingleses en Singapur y los holandeses en Java (19) y no, como ha venido repitiéndose, en el preexistente monopolio español del tabaco.

Sin embargo, como apunta Wickberg, conviene recalcar que, a diferencia de otras rentas públicas como las obtenidas por las peleas de gallos, las loterías y las ventas de tabaco, que tasaban prácticas socialmente aceptadas, las rentas del opio establecían un impuesto sobre una actividad que se consideraba reprobable (20). En este sentido, no puede decirse que el sistema español fuera una consecuencia de la tolerancia respecto a la comunidad china, de la que se detestaban sus costumbres, sino una concesión a ese grupo étnico a cambio de acrecentar las oportunidades económicas que para la colonia ofrecía su presencia.

(19) Trockl, [4], págs. 70-78; y J. R. Rush. Opium to Java. Revenue Farming and Chinese Enterprise in Colonial Indonesia, 1860-1910. Ithaca: Cornell University Press, 1990, págs. 43-64.

(20) E. B. WickBerg. The Chinese in Philippine Life, 1850-1898. New Haven: Yale University Press, 1965, pág. 118. El impuesto que sobre las riñas de gallos se estableció en 1861 ilustra bien este punto. La gallera era un entrelenimiento tan popular que sus impuestos generaban sólidos beneficios y algunos de los chinos y mestizos más ricos pujaron por sus contratas. Los americanos, por el contrario, encontraron odiosa tal diversión y trataron constantemente de sustituirla por otras más "edificantes", como el beisbol. Véase H. Norman. The Peoples and Politics of the Far East. Londres: T. F. Unwin, 1900, pág. 178. 
El sistema, por lo tanto, se basaba en la posibilidad de establecer una distinción taxativa entre chinos y no chinos. Sólo a los chinos les estaba permitido visitar los "fumaderos de anfión" y a este respecto los bandos "señalaban los sitios en que debían establecerse los fumaderos y las reglas para su introducción por los asentistas" y prohibían, bajo las mismas severas penas de 1814, que indios o mestizos fumasen opio (21). Por lo tanto, el monopolio del opio se basó en la segregación étnica y cultural. La posibilidad legal de usar opio era una más de las distinciones legales de los grupos étnicos de Filipinas. En consecuencia, es preciso comprender, siquiera sea sumariamente, el sistema de grupos étnicos en las Filipinas españolas y el cambiante papel de los chinos en tal sistema.

\section{GRUPOS ÉtNicos EN FiliPINAS: LOS ChINOS}

Sobre la variada realidad étnica del archipiélago, que incluía a cientos de grupos indígenas cultural y língüísticamente diversos, la administración española impuso un sistema de control simplificado en el que reconocían tres grandes grupos con distintos papeles en el orden colonial y con categoria legal diferenciada: los nativos o indios, los chinos o sangleyes y los españoles o castilas. Tal fragmentación de la población, sin embargo, era más cultural que racial, ya que el sistema permitía una considerable movilidad socioeconómica y un elevado grado de asimilación a través del matrimonio o la conversión religiosa. Con el paso del tiempo, este modelo étnico fue haciéndose más complejo, aumentando el número de grupos reconocidos en el sistema colonial, debido sobre todo al mestizaje y la inmigración. Así, el sector dominante y no contribuyente de los españoles se dividió entre peninsulares, nacidos en España, criollos o insulares, nacidos en Filipinas y los mestizos de español y aborigen. Entre esos tres grupos existían claras distinciones de influencia y estatus social, aunque no verdaderas diferencias legales.

El complejo étnico se complicó también con la creciente presencia de mestizos chinos, sobre todo a partir del siglo XVIII, que marcó, en éste como en otros temas, una divisoria fundamental. Los mestizos de sangley, mucho más numerosos e importantes que los de español, se asimilaron a la cultura local, siendo considerados sujetos indígenas de España («nacionales») y no extran-

(21) MONTERo [14], vol. 3, pág. 64. 
jeros como los chinos. De hecho, los mestizos chinos no se diferenciaban de los indios en su estatus legal más que en el aspecto impositivo. De los tres grupos contribuyentes, los mestizos chinos pagaban más que los indios, pero menos que los chinos (22).

Los chinos de Filipinas son una más, si bien peculiar, de las importantes minorías de chinos de ultramar que dominan gran parte del comercio y las finanzas en casi todos los países del sudeste asiático (23). Su presencia en Filipinas es muy anterior a la llegada de los españoles, remontándose, al menos, al siglo XII. Los españoles llamaron a los chinos "sangleyes", término probablemente derivado del chino "shang-lü» - mercader viajerocon el que los chinos solían identificarse (24). Estos sangleyes fueron uno de los extremos del eje comercial que, mediante el galeón, mantuvo el dominio español en Filipinas durante sus dos primeros siglos. Tanto españoles como chinos obtuvieron con ese comercio pingües beneficios y Manila se convirtió rápidamente en nódulo del sistema comercial transcontinental que, según Chaunu, constituyó el primer sistema económico mundial moderno (25). El comercio con América estimuló la inmigración china a Manila que se convirtió en la metrópoli del archipiélago y en "una ciudad no sólo española, sino también china» (26).

A pesar de la interdependencia económica, las relaciones entre chinos y españoles estuvieron siempre marcadas por un antagonismo cultural irreconciliable (27). La desconfianza y la hostilidad mutuas explotaron frecuentemente en "masacres sangrientas de chinos" que se repitieron periódicamente hasta el siglo XIX. A pesar de tales crisis, la mutua necesidad volvía a reafirmarse rápidamente y la comunidad china volvía a crecer, pues «a pesar de los enraizados antagonismos raciales [y culturales], ni los españoles ni los chinos podían pasarse los unos sin los otros" (28).

En la segunda mitad del siglo XVIII se estimuló en Filipinas el

(22) Idem, Ibidem, vol. 3, pág. 83

(23) W. F. Wertheim, "The Trading Minorities in Southeast Asia" en Sociological Approaches to Modern Asia. Chicago: Quadruple Books, 1964, págs. 39-82; V. Purcell. The Chinese in Southeast Asia. Londres, Oxford University Press. 2." ed., 1965, págs. 2-30.

(24) Y. Z. CHANG, "Sangley, the Merchant Traveller." Modern Language Notes. 1937, vol. 52, pág. 189. Véase TAN, [1], 15, donde se of rece un compendio de obras sobre la presencia prehispánica de los chinos en el archipiélago.

(25) P. Chaunu. Les Philippines et le Pacifique des Iberiques (XVI ${ }^{\circ} \mathrm{XVII}^{\circ}$ XVIIIe siècles): introduction methodologique et indices d'activité. Paris, S.E.V.P.E.N., 1960

(26) WoLF, [10], pág. 153.

(27) WiCKBERG, [20], pág. 9.

(28) J. L. Phelan, The Hispanization of the Philippines. Spanish Aims and Filipino responses, 1565-1700. Madison: University of Wisconsin Press, 1959, pág. 11. 
cultivo de cosechas comerciales como el azúcar, el añil, las especias y, sobre todo, el tabaco. La creación del monopolio del tabaco en 1781 y de la Real Compañía de Filipinas en 1785, así como la apertura del comercio directo entre la Península y Filipinas permitieron a la administración terminar con la dependencia secular del "situado" mexicano acabando con la "pesadilla fiscal» que había supuesto el archipiélago para la hacienda española (29).

La menor importancia de la "nao de Acapulco» redujo el papel económico de los chinos, cuya presencia en el archipiélago se vio reducida por sucesivas expulsiones. Tras la última expulsión de 1769 se alcanzó un mínimo de presencia china en Filipinas que habría de durar hasta 1846. Los mestizos chinos, competidores de los chinos en muchas industrias, fueron los principales beneficiarios de su marcha, «el fenómeno social más importante de la centuria que va de 1750 a 1850 fue el ascenso de los mestizos chinos a una posición de preeminencia social y económica" (30).

Esa tendencia a la baja de la presencia china en Filipinas no se invertiría hasta la segunda mitad del siglo XIX. La pérdida de las colonias de América y la creciente penetración europea en Asia forzó un cambio en la administración española, en la que fueron ganando terreno las tesis liberales, volviendo a reanudarse la inmigración china al archipiélago. Ciertos hitos en la liberalización del comercio en las islas facilitaron esa transición. Entre ellos destacan el fin del monopolio de los gobernadores de provincias en 1844 y el de las restricciones legales para que los chinos residieran fuera de Manila, en 1849 (31). Importantes acon-

(29) M. L. Dfaz-Trechuelo. La Real Compañia de Filipinas. Sevilla: Escuela de Estudios Hispano-Americanos (CSIC), 1965. págs. 264-75

(30) A diferencia de los mestizos chinos en otras colonias europeas del sudeste asiático -el peranakan de Indonesia o el baba de Malasia- el mestizo chino-malayo en Filipinas "no era una clase especial de chino, sino una clase especial de filipino" (véase WICKBERG [20], págs. 25 y 31 ), una clase tan importante en la moderna identidad filipina que los mestizos chinos y sus descendientes han constituido la élite más importante junto con los nativos urbanizados, en la configuración del nacionalismo filipino (véase WICKBERG [17], pág. 62; J. T. OMOHUndro, Chinese Merchant Families in Iloilo: Commerce and Kin in a Central Philippine City. Quezon City: Ohio University Press, 1981, pág. 17). Baste recordar que fueron mestizos o descendientes de mestizos figuras tales como Rizal, Osmeña, Quezón y, más recientemente, Fernando Marcos. Este fenómeno muestra una vez más las diferencias entre los sistemas étnicos producidos por las potencias latinas y católicas como Portugal, Francia y España en sus colonias, más etnocéntricós que racistas, $\mathrm{y}$ las protestantes y germánicas como Holanda, Inglaterra o Alemania que han tendido hacia lo contrario.

(31) Otros hitos importante en la globalización del comercio y las comunicaciones, como la apertura del canal de Suez. en 1863, contribuyeron también a revitalizar la demografía y la economia filipina. 
tecimientos regionales como la fundación de Hong Kong por los británicos, el establecimiento de líneas regulares marítimas a vapor y las desastrosas condiciones de vida en China durante la cruenta rebelión Taiping (1850-1864) contribuyeron también a disparar la inmigración de sangleyes a Filipinas. Así, mientras en 1847 el número de chinos en el archipiélago se mantenía en un nivel mínimo de unos 5.700, dentro de una población total de unos 3,5 millones, en 1880 el número real de chinos superaba los 90.000 , en una población total de unos 6 millones de filipinos. Entre el 48 y el 60 por ciento de la población china residía entonces en Manila (32).

En pocos años, los sangleyes aumentaron vertiginosamente su influencia económica en el archipiélago. Se aprovecharon para ello de las nuevas oportunidades que les brindaba la economía de exportación, de su mayor experiencia y sofisticación comercial y de sus contactos mercantiles y financieros que facilitaban su acceso a mercados exteriores y a crédito (33). El crecimiento entre 1820 y 1870 de una economía colonial de exportación, basada en productos como el azúcar, café, abacá, añil, tabaco y, por un tiempo, incluso arroz, ofreció a los chinos amplias oportunidades de medro; de este modo, entre 1846 y 1880 se intensificó de tal manera su papel en la economía filipina que no sólo recuperaron la posición que habían tenido hasta 1750, sino que «superaron todos sus éxitos previos» arrebatando a los mestizos la primacía en muchos sectores comerciales (34). Donde primero y más notoriamente ascendieron los chinos fue en el comercio al detalle. El control de dicho comercio les permitió, a su vez, penetrar en todas las regiones productivas, adquiriendo allí una gran parte de las cosechas de exportación directamente de los cultivadores, mediante el trueque de los productos de sus tiendas y los préstamos y anticipos. Los chinos establecieron así una trama de redes comerciales que enlazaban el comercio al detalle y al por mayor, llegando a ejercer una enorme influencia en todas los cultivos comerciales, excepto el del café (35).

El progreso económico de los sangleyes intensificó el odio étnico hacia ellos, hasta tal punto que, en la década de 1880, la minoría china en Filipinas había entrado en un nuevo período de

(32) WiCKVERG, [20], pág. 61.

(33) Idem, pág. 121.

(34) Idem, pág. 119.

(35) Idem, pág. 77, págs. 94-103; B. Legarda y FernánDEZ.. "The Philippine Economy under Spanish Rule". Solidarity Manila, 1967, vol. 2, nº 10, págs. 1-12. 
inseguridad política y social. Frente a las presiones tanto de peninsulares como de criollos y mestizos, los chinos reaccionaron intensificando su sentido comunitario y su orgullo cultural, orientado ahora cada vez más hacia una identidad nacionalista compartida con el contiente. A pesar de las diferencias internas, por primera vez fueron los sangleyes una comunidad organizada en Filipinas (36). En este contexto, los españoles contemplaron el monopolio del opio como un medio más de forzar a los chinos a dejar parte de sus ingresos en Filipinas y en ese sentido era congruente con los objetivos tanto de conservadores como de liberales, por más que hiriese la sensibilidad de algunos sectores del clero de la época (37). Ese es quizá uno de los motivos esenciales de la continuidad de las rentas de anfión y de su "éxito".

\section{EL MONOPOLIO DEL OPIO: LAS RENTAS DE ANFIÓN}

A diferencia del monopolio del tabaco, que incluía el control del cultivo y la elaboración y venta de los cigarros por parte del gobierno (38), el del opio suponía la cesión del monopolio a empresarios particulares a cuyo cargo corrían todas las fases del comercio, desde la importación y preparación del producto, hasta su distribución a los fumaderos, incluyendo el control del mercado negro y del contrabando.

El sistema, a grandes trazos, funcionaba así: en cada provincia donde residían suficientes usuarios chinos los derechos de explotación se subastaban por tres años. El contratista que ganaba la subasta tenía que importar el opio, almacenarlo en locales especiales bajo control de aduanas y establecer o proveer tantos fumaderos como fueran necesarios para abastecer a los consumidores locales. Todos los fumaderos debían tener la conveniente licencia gubernamental y vender opio de calidad estándar, que los asiduos debían fumar en el establecimiento y en ninguna otra parte. El contratista podía usar los factores y empleados que estimase oportuno para el eficaz desempeño de su negocio,

(36) Véase Omohundro [30], pág. 17 y WickBerg [20], pág. 147.

(37) Véase LA OCEANIA ESPAÑOLA. Los Chinos en Filipinas: males que se experimentan actualmente y peligros de esa creciente inmigración. Manila, 1886.

(38) C. C. Pi.enn. "Taxation in the Philippines, I y II" Political Science Quaterly. 1901, vol. 16, págs. 680-711; vol. 17, págs. 125-48. J. L. Ll.ANES. "The Tobaco Monopoly in the Philippines during the Spanish Regime (1782-1881)" Ilocos Review. 1988, vol. 20, no de diciembre, págs. 35-54. 
así como subcontratar toda o parte de la concesión o de los servicios asociados. Podía también defenderse de la competencia desleal denunciando a los contrabandistas y vendedores ilegales que infringieran el monopolio en su provincia.

El opio, usualmente del tipo Patna o Benarés, se importaba desde Bengala a través de Hong Kong hasta las islas del norte, y de Zamboanga o Joló a las del sur. La importación era gravosa, pues además de la compra de la materia prima y los costes del flete, el opio pagaba también la tarifa sobre drogas y una tasa especial de 40 pesos por caja, que se elevó en 1890 a 50 pesos (39). Esos ingresos y los de las contratas no eran los únicos que el comercio del opio proporcionaba al gobierno; en las arcas del tesoro entraban también los impuestos pagados por los diversos intermediarios, incluidos los propietarios de los fumaderos, quienes, además de la cédula personal, habían de pagar la «contribución industrial» por su negocio.

El crecimiento de las "rentas de anfión» es un claro índice de la creciente presencia de los chinos en el archipiélago. Por ejemplo, mientras en 1859 el monopolio del opio produjo al Estado español unos ingresos de 44.333 pesos; en 1894 los ingresos por tal concepto sumaban 602.300 pesos, es decir quince veces más en términos absolutos. La inflación acumulada durante esos años no basta para explicar tal aumento, pues la aportación de las rentas de anfión al presupuesto general filipino se multiplicó por diez en ese período, pasando del 0,44 al 4,4 por ciento (40).

En concreto, tenemos datos sobre Cagayán e Isabela, provincias tabaqueras por excelencia que, en el caso del opio, compartían estanco. El de Cagayán-Isabela era un contrato medio; muchas otras provincias tenían en los años noventa contratos superiores. En 1892, por ejemplo había en ambas provincias cuarenta fumaderos con licencia, lo que podría suponer unos 1.500 usuarios regulares de opio. En comparación, la provincia de Iloilo tenía cien fumaderos por lo que su contrata, para la que no hemos encontrado datos, debía de ser mucho mayor (41).

(39) E. Plauchut. "L'Archipel des Philippines" Revue des deux mondes. 1877, vol. 21, págs. 885-887; R. González FERnández y F. Moreno Jterlz. Manual del viajero en Filipinas. Manila, Est. Tip. de Santo Tomás, 1875, págs. 204-5.; WICKBt:RG [20], pág. 116.

(40) LEGARDA [35], págs. 20-21.

(41) WickBerg; [20], pág. 116. 
Tabla 1. Precios Pagados POR la CONTRATa del ANFión EN La PROVINCIA DE CAGAYAN-ISABELA

\begin{tabular}{ll}
\hline Años & Pesos \\
\hline 1869 & 15.150 \\
1872 & 16.150 \\
1875 & 17.150 \\
1878 & 19.525 \\
1881 & 24.570 \\
1884 & 26.500 \\
1887 & 56.610 \\
1892 & 81.200 \\
1895 & 39.600 \\
\hline
\end{tabular}

Fuente: PNA. Rentas de Anfión, 15-10-9.

El crecimiento de los precios que alcanzaban las subastas de las concesiones de opio refleja con claridad el aumento de la presencia china en ambas provincias. El salto en los precios pagados por las contratas es especialmente dramático en la segunda mitad de los ochenta, cuando el fin del monopolio del cultivo y la manufactura del tabaco (que no de su venta), atrajo una numerosa población china a esa región. La presencia de los sangleyes en las provincias tabaqueras no era bien vista; se les acusaba de hacerse con los mejores terrenos para el cultivo de tabaco "por efecto de préstamos hipotecarios o de pactos de retro" y de degradar después el producto (42).

El monopolio del opio fue de importancia creciente para la hacienda pública filipina, si bien nunca llegó a ser tan decisivo como a veces se pretende. Los ingresos por rentas de anfión nunca llegaron a rebasar el 5 por ciento del total del presupuesto filipino, manteniéndose siempre en una situación secundaria respecto a otros monopolios estatales, como el de las loterías $y$, sobre todo, el del tabaco, cancelado en 1881. Por ejemplo, la cantidad producida por el estanco de opio en 1859 no era ni el uno por ciento de los más de cinco millones de pesos que produjo en esa fecha el estanco del tabaco; y los citados 602.300 pesos producidos en el apogeo del monopolio de opio en 1894 permanecen por debajo de los 873.000 pesos que en la misma fecha produjeron los impuestos por apuestas de lotería.

(42) La Oceania Española |37]. 
Durante la insurrección independentista de 1896, que tanto afectó a la economía de las islas, en casi todas las provincias hubo dificultades para mantener el monopolio, lo que supuso pérdidas para muchos contratistas. A partir de entonces muchas contratas se quedaron sin cubrir o se negociaron mes a mes. Donde la insurrección fue más intensa, como en Cavite, los chinos se sintieron inseguros y huyeron a Manila. Al perder allí su negocio por falta de clientes, el contratista local se declaró en bancarrota (43). Tras el bloqueo de Manila por el almirante Dewey, se hizo imposible la importación o el traslado por mar del opio almacenado en Manila y el monopolio español del opio dejó de existir.

\section{LOS CONTRATISTAS}

Para cada subasta el gobierno establecía una cantidad mínima, usualmente la alcanzada en el trienio anterior, que se esperaba rebasar en la puja. Hubo años, sin embargo, en que los precios de salida hacían imposible obtener los beneficios esperados y los contratistas boicotearon las subastas. En estas ocasiones el gobierno se veía obligado a bajar los precios, lo que generalmente se hacía mediante descuentos del 5 por ciento (44).

Siguiendo el análisis del sistema de impuestos filipino en el siglo XIX realizado por Plehn (45), es posible hacerse una idea de los beneficios que el monopolio reportaba a los contratistas. Como impuesto directo sobre sus ingresos, los contratistas pagaban cada tres años un 0,5 por ciento del precio total de la contrata. Teniendo en cuenta que la política del gobierno consistía en tasar la renta de las personas físicas en un 5 por ciento, se puede calcular que cada contratista consiguiera beneficios de, al menos, un 10 por ciento del valor de la concesión en subasta. Así, la contrata de Manila para 1890-93, que alcanzó un precio de 532.127 pesos, debió producirle al contratista unos beneficios superiores a los 50.000 pesos, una cantidad muy considerable en aquella época.

(43) PNA: Rentas de Anfión, 6-2-9. Expediente relativo a Cavite, 1896. (Seguimos la clasificación de Wickberg, cuya copia microfilmada de los archivos filipinos hemos utilizado. E. B. WickBERG. Philippine National Archives. 1953. Film, University of California, Berkeley).

(44) Véanse, por ejemplo, los expedientes relativos a Romblón, 1895 y Calamianes, 1897. PNA. Rentas de Anfión, 37-2-10.

(45) PlehN [38], págs. 705-706. 
Con frecuencia se afirma que los contratos de anfión fueron una tarea a la que se dedicaron exclusivamente los chinos; pero esto no es cierto. Es verdad que varios de los empresarios chinos más importantes de Manila fueron contratistas de opio; sin embargo hubo también españoles, mestizos e indígenas dedicados a ese negocio. Por ejemplo, un español, Eulogio Mendoza, obtuvo las contratas de Leyte, Cavite y Samar en 1890 en comandita con dos comerciantes chinos (46). El arrendatario de Cavite en 1892 y 1896 también era peninsular; finalmente, la contrata de Manila, la mayor de todas con diferencia, fue varias veces ganada por empresarios españoles.

La presencia de mestizos en el negocio era también común y aceptada. A título de anécdota, basta hablar del Capitán Tiago, personaje de las novelas de José Rizal «Noli me Tangere» y «El Filibusterismo", legalmente un mestizo, pero más probablemente un indio que había comprado su acceso a la privilegiada clase de los mestizos (47). El capitán Tiago «era considerado como uno de los más ricos propietarios de Binondo y uno de los más importantes hacenderos por sus terrenos en la Pampanga, en la laguna de Bay y en el pueblo de San Diego... y la contrata del opio la explotaban él y un chino, y ocioso es decir que sacaban grandísimos beneficios. Daba de comer a los presos de Bilibid y suministraba zacate (forraje de caballerías) a muchas casas principales de Manila, mediante la correspondiente contrata, como es natural» (48).

Tampoco debe pensarse por lo dicho antes que los chinos siempre actuaban de común acuerdo. La competencia entre los diversos grupos chinos era con frecuencia muy dura y hacía subir los precios de Ias contratas en subastas. Por ejemplo, el ganador de la subasta de 1892 fue Federico Gamir Co Sequieng (49), un comerciante chino de Manila dueño de varias fábricas de tabaco y con contactos extensos en el negocio del opio, se hizo con la contrata de Isabela-Cagayán compitiendo

(46) PNA: Rentas de Anfión, 15-10-9.

(47) J. Riz.AL. El Filibusterimo (continuación de Noli me Tangere) Barcelona. Casa editorial Maucci, 1911 (1.“ ed. 1891), pág. 37. El Capitán Tiago "había sido gobernadorcillo del rico gremio de mestizos, a pesar de la protesta de muchos que no le tenían por tal".

(48) J. Rizal, Noli me tangere (el pais de los frailes): Novela Tagala. Valencia, Sempere y Cía., 1910 (1. 'ed. 1886), pág. 35.

(49) Era costumbre que los chinos tomasen el nombre de su padrino al bautizarse. 
contra el poderoso Carlos Palanca Tan Quiensien, que apoyaba a su principal oponente (50).

En la colonia española se daba por lo tanto la situación -paradójica desde nuestra perspectiva actual- de un sistema de distribución y venta de opio en el que podía participar cualquiera, aunque el consumo de ese fármaco le estaba terminantemente prohibido a la mayoría (51).

\section{VENTA Y CONSUMO: LOS FUMADEROS DE ANFIÓN}

Como ya hemos apuntado, durante los primeros años la venta del opio estuvo limitada a la zona de Manila, donde una sección de la Alcaicería de San Fernando se utilizó como fumadero gubernamental. En 1850, el contratista del monopolio, un prominente empresario español, consiguió que se subastasen contratos también para las provincias vecinas y los fumaderos se fueron extendiendo por el archipiélago (52). Diez años después, en 1860, el viajero alemán Jagor reportaba la existencia de 478 fumaderos con licencia del gobierno en todo el país, además de cientos de chinos que fumaban anfión en sus domicilios (53). Si aceptamos la estimación oficial de unos 30 clientes iniciales por fumadero (54), podemos hablar de unos quince mil usuarios de opio en Filipinas para esa fecha.

Respecto al consumo individual, sabemos que en 1873 se importaron 17.163 kilogramos de opio a Filipinas (55) y si aceptamos para entonces una cifra conservadora de quince mil usuarios, obtenemos un consumo anual medio por usuario de unos 3,1 gramos por día, lo que podría indicar, como en el caso de Java, un predominio del consumo moderado sobre el intoxicante (56). Tal hipótesis se ve corroborada por declaraciones de observadores

(50) PNA: Ramo de Anfión, 5-20-12.

(51) La venta al por menor estaba limitada a los chinos, pues todos los demás grupos étnicos tenían prohibida la entrada en los fumaderos.

(52) PNA: Reales Ordenes, caja 108, núm. 12 y 36.

(53) F. JagOR. Travels in the Philippines. Originalmente publicada en London: Chapman and Hall. 1875; versión utilizada: E. H. BlaIR y J. A. RoBERTSON. The Philippine Islands, 1493-1898. 55 volúmenes. Cleveland: Arthur Clark Co., 1907, vol. 52, págs. 309-10 y 318 .

(54) WiCKBERG [20], pág. 118.

(55) GONZÁLEZ y MORENO [39], págs. 204-5.

(56) A. Esconotado. Historia general de las drogas. Madrid: Alianza editorial, 1989; Rush [19], pág. 39. 
locales, como las ya citadas del juez Bernáldez y las de Comenge (57).

Para la sociedad filipina los fumaderos eran, en su mayoría, sitios de mala nota, "semilleros de inmoralidad" les llama Jagor (58), donde se reunían hombres que, a pesar de su diligencia y laboriosidad, estaban marginados de la sociedad local; hombres que hablaban una lengua desconocida, practicaban una religión "pagana" y acudían allí a entregarse a vicios extraños.

Es posible asomarse a la existencia de esos chinos de a pie que visitaban los fumaderos. Casi todos eran varones, jóvenes solteros o, si casados, habiendo dejado su mujer e hijos en el continente. El trabajador chino se encontraba al llegar a Manila "encadenado al trabajo, quién sabe por cuanto tiempo. Debe algunos pesos mexicanos, una fortuna... añádase... el costo del viaje, la indumentaria precisa para exhibirse entre cristianos... la deuda sube y el interés agobia con su peso a estos desdichados», que tenían ante sí años de duro trabajo (59). Las condiciones del viaje solían ser pésimas. Comenge habla de los buques que llegaban al puerto de Manila «infestados de chinos... que no traen más equipaje que lo puesto" y que durante la travesía "apenas comen, un puñado de arroz cocido, un pescado seco al sol», mientras "algún conductor y sátrapa entre aquella gente fuma opio, los emigrantes (que) no pican tan alto, le miran con envidia, se encojen y agazapan junto a la mura y duermen" (60). Ya en el puerto «el gobernadorcillo exije de cada pasajero el importe anual de la cédula que a cada uno corresponde... El que no paga no desembarca y si no se presenta persona que le anticipe el dínero... el capitán del buque... tiene obligación de devolverle al puerto donde procede». Caen así bajo el control de un pariente o. de un empresario o "cabecilla" de chinos (61).

El emigrante solía empezar a trabajar en las tareas más humildes y arduas. El sangley era generalmente muy laborioso: «un trabajador a destajo imposible: Ponen en todo un ardor, una vehemencia que asombra» (62). Es comprensible que esos emigrantes pasasen en los fumaderos sus raros momentos de asueto en compañía de sus paisanos. Lejos aún de poder establecerse y 1886

(57) R. Comenge, Los chinos. Estudio social y político. Manila: Chofre y Cía.,

(58) Bi.Air y RoBERTSON [53], vol. 52, págs. 310.

(59) ComenGe [57], pág. 38.

(60) Idem, págs. 28-29.

(61) Idem, pág. 35.

(62) Idem, pág. 45. 
contraer matrimonio con alguna nativa, es de suponer también que los sangleyes tratasen prostitutas, y sobre tal aspecto existen datos fehacientes. Como ha mostrado Camagay, en sus estudios sobre la prostitución en Manila en el siglo pasado, había todo un grupo de prostitutas que «acudían al domicilio del cliente», quienes se dedicaban casi exclusivamente al comercio con chinos. Ese es el caso de las tres «visitadoras» "Paula Prim, Andrea Austria y Serapia Roncal, arrestadas en un almacén de jabón que pertenecía a un chino de nombre Sy Jacon, y el de Plácida Gabriel, una viuda de treinta y dos años de la que se afirmaba tenía muchos clientes entre los chinos, así como de otras mujeres acusadas de prostitución que fueron arrestadas en los «fumaderos de los chinos», lo que parece apuntar que "los fumaderos servían también en muchos casos como burdeles» (63).

Por otra parte, los datos muestran con claridad que el uso del opio se había extendido a todos los estratos de la comunidad china. Conocemos casos de dependencia al opio en los sectores más adinerados, por ejemplo entre las ricas familias de Amoy que en Iloilo hicieron grandes fortunas en la exportación y que mantenían casas en Fukien, llegando a tener varias mujeres y concubinas a ambos lados del mar. Muchos de los retoños de esas familias "sucumbieron con frecuencia al hábito del opio" (64). Los chinos más ricos, sin embargo, se negaban a frecuentar los fumaderos públicos y las autoridades españolas les ofrecieron la alternativa de establecer otros más lujosos y exclusivos en Manila. En el resto de las provincias el gobierno hizo la vista gorda al uso privado de opio por chinos de alto estatus, que no gustaban de mezclarse en sus "vicios" con el populacho. A ellos se les permitió consumir opio en sus casas, siempre que lo comprasen al contratista legal (65).

En 1896 ocurrió un caso curioso que ilustra este tema, cuando un nuevo inspector español pletórico de rigor reglamentista llegó a Iloilo y encontró que de los 100 fumaderos con licencia en la provincia, 56 eran privados, es decir, admitían sólo a unos cuantos miembros selectos. Escandalizado, envió un informe sobre la situación a la administración de hacienda en Manila, de donde le respondieron que lo que denunciaba era conocido y tolerado, y que tales acuerdos bajo cuerda ocurrían también en otras regio-

(63) M. L. CamagaY, "Prostitution in Nineteenth Century Manila" Philippine" Studies. 1988, vol. 36, págs. 249-50).

(64) OMOHUNDRO [30], pág. 21.

(65) PNA: Reales Ordenes, caja 108. 
nes, siendo la única forma de hacer rentable el monopolio (66). El hecho prueba como, de la misma forma que en China, el consumo de opio en Filipinas no estaba restringido a ninguna clase social.

Conviene resaltar que, dada la condición legal de los chinos en el archipiélago, era fácil para la administración española permitir el consumo del opio. Las consecuencias negativas de tal consumo no corrían a cargo de la sociedad que tasaba su uso. Los chinos eran sobre todo "materia imponible», que podía ser arrojada fuera de los límites de la responsabilidad del Estado cuando fuere necesario. Por eso, para las autoridades españolas, el uso dañino del opio por parte de los sangleyes era sólo preocupante en tanto que impidiera al individuo la satisfacción de las obligaciones individuales con la cosa pública, sobre todo con su hacienda. Así Comenge nos describe la cubierta de un vapor que parte del puerto de Manila rumbo a Cantón y sobre la que yacían:

un grupo de chinos sucios y astrosos mirando con ojos estúpidos... Son los deudores del fisco... que por insolventes son devueltos al celeste imperio... son los gandules, los que, embrutecidos por el anfión, han gastado su fortuna y su crédito, miembros corrompidos que la sociedad filipina arroja lejos de sí (67).

Es importante señalar cómo la legislación española exigía que el fumar opio fuese un vicio público. Los fumaderos debían estar abiertos a todos los chinos y el opio debía consumirse sólo allí. Era una estrategía de control social que trataba de evitar la extensión o contaminación de la práctica a los nativos, tanto indios como «mestizos de sangley», a quienes les estaba prohibido entrar en los fumaderos. El propietario del establecimiento corría también el riesgo de ser castigado si aceptaba clientes que no fueran chinos.

Por los datos a nuestro alcance parece que el sistema cumplió su propósito y que el fumar opio continuó siendo una costumbre exclusiva de los chinos. Las excepciones debieron de ser pocas y limitadas a ciertos miembros influyentes de la sociedad local. Ese podría ser el caso del Capitan Tiago, el personaje de Rizal del que ya hemos' hablado, al que la desgracia llevó a dedicar su vida "al liam-pó y a la gallera y... a fumar opio», vicios todos que

(66) PNA: rentas de Anfión, 6-2-9.

(67) Comenge [57], pág. 57. 
le apartaron de la «buena sociedad» filipina y que precipitaron su ruina:

Si alguna vez al caer la tarde os paseáis por la primera calle de Santo Cristo, veréis sentado en la tienda de un chino un hombre pequeño, amarillo, flaco, encorvado, con los ojos hundidos y soñolientos, labios y uñas de un color sucio, contemplando a la gente con mirada estúpida. Al llegar la tarde le veréis levantarse con trabajo y apoyado en un bastón dirigirse a una sucia casucha, encima de cuya puerta se lee en grandes letras rojas: Fumadero público de Anfión. Este es aquel Capitán Tiago tan célebre, hoy completamente olvidado (68).

En cualquier caso, aquí presentamos una visión externa del mundo chino en Filipinas. Las descripciones que manejamos son las de filipinos 'y españoles, extraños ambos a la comunidad sangley que percibían nublada por un cúmulo de estereotipos $\mathbf{y}$ resentimientos. Resulta difícil saber qué ocurría de verdad en los fumaderos, cómo se vivía el hábito del opio dentro de la comunidad china. En este sentido es importante la entrevista con Tee Han Tee, un comerciante chino residente en Manila, llevada a cabo en 1904 por el Comité nombrado por el Gobierno Civil norteamericano. Tee afirmaba que, si bien el anfión era usado por chinos de toda clase y condición, la mayoría de ellos, incluso los adictos, encontraban vituperable el uso habitual e inmoderado. Según Tee el opio era para sus paisanos uno de sus "remedios familiares" más apreciados y, aunque los médicos chinos lo prescribían poco, "si un miembro de la familia, un hermano, una hermana o un tío, sufre de alguna dolencia, es muy común recomendarle que tome una pipa de opion (69).

El vicio del opio, por tanto, era también para los chinos un vicio a ocultar, del que no se sentían orgullosos, pero que había llegado a formar parte de sus costumbres y del que se hacía un uso que rebasaba con mucho los estereotipos de la visión externa, siendo muchas veces una forma más de automedicación, una faceta del uso de los fármacos psicoactivos rara vez se integra en la visión moralista de «la droga».

(68) Rizal [48], pág. 227.

(69) C. PH. C. Senate. 59th Congress. March, 1906. "Repport of the Committe Appointed by the Philippine Commission to investigate the Use of opium and the Traffic Therein". Washington D. C. pág. 146. 


\section{EL SISTEMA NORTEAMERICANO (1898-1908)}

La anexión de Filipinas, que culminaba su expansión a través del Pacífico, confirió a Estados Unidos un nuevo estatus internacional: el de potencia colonial en Asia. En principio, el archipiélago filipino se percibió como una base ideal para la penetración económica en el continente, sobre todo en China. No olvidemos que esos años coinciden con la formación de los gigantescos monopolios americanos y con una crisis económica, tras la gran depresión de 1893, que veía en los mercados de oriente una atractiva salida para los productos metropolitanos (70). Eran los años del apogeo de esa nueva fase en la expresión mundial del capitalismo, que Hobsbawm ha llamado la «era imperial» (71).

Pronto, sin embargo, las islas Filipinas se volvieron más atractivas por sí mismas y los grupos más interesados en su anexión (la armada, los círculos misioneros y amplios sectores industriales y financieros) se esforzaron por armonizar el moralismo interesado, el beneficio económico y las ventajas estratégicas en favor de aquel ejercicio de "altruismo internacional» (72).

La racionalización básica que justificó la anexión de las islas fue simple; los filipinos no estaban aún capacitados para el autogobierno y abandonados a sí mismos caerían en una anarquía y un desorden aún peor que los que sufrían bajo el gobierno de España. En este sentido, se hizo un esfuerzo por distinguirse de las potencias coloniales europeas, especialmente frente a la opinión pública norteamericana, en la que resonaban poderosas voces anti-imperialistas. En este empeño, el del opio era un tema de gran importancia ideológica y propagandística. "Con la adquisición de Filipinas, los Estados Unidos adquirieron un interés concreto en la situación de las drogas en Extremo Oriente» (73).

\section{LA ANEXIÓN DE FILIPINAS Y EL PROBLEMA DEL OPIO}

Cuando las tropas americanas entraron en Manila en agosto de 1898, el gobierno militar canceló el monopolio español del opio e impuso una tarifa (la «Tariff Act» que imperaba en Estados

(70) Musto [3], pág. 24; W. J. Pomeroy, American Noe-Colonialism. Its Emergency in the Philipipines and Asia. Nueva York: International Publishers. 1970, pág. 19

(71) E. J. Hobsbawn The Age of Empiere: 1875-1914. Nueva York: Pantheon. 1987, págs. 9-12.

(72) POMEROY [70], pág. 11.

(73) TAYLOR [5], pág. 328. 
Unidos) sobre su venta. Poco después se publicaron ordenanzas municipales en pueblos y ciudades que prohibían el establecimiento de fumaderos públicos (74). El del opio, sin embargo, era en aquellos momentos uno de los problemas menores del mando militar norteamericano, que se enfrentaba a una guerra sin cuartel contra los independentistas filipinos, a quienes sólo consiguió doblegar tras tres años de lucha brutal, con un coste para la población nativa de cientos de miles de muertos (75).

En julio de 1901 los militares transfirieron formalmente el gobierno de las islas a la Comisión Filipina, encabezada por el primer gobernador civil, William H. Taft. Hasta julio de 1902, sin embargo, cuando se dio por terminada oficialmente la guerra -la rebelión que continuó en algunas provincias se consideró vulgar "bandolerismo»- no pasó el mando militar a un segundo plano, sobre todo en Manila y en las otras áreas «pacificadas» (76).

Taft era un hábil y enérgico político conservador, muy ligado a las grandes corporaciones industriales, que había llegado a Filipinas deseoso de abrir el archipiélago a los intereses comerciales norteamericanos. Mucho más sutil y contemporizador que los militares, su gobierno abrió un nuevo período de atracción de las élites locales hacia la colaboración con el nuevo poder establecido.

El problema del opio apareció con urgencia en la agenda del gobierno Taft. A principios de 1903, "diversos informes de varias provincias y otras fuentes de la capital convencieron a la Comisión de que el uso de opio crecía entre el pueblo filipino" (77). La práctica se estaba extendiendo como "fuego en el bosque», pues los filipinos habían sido "contaminados por el vicio" no sólo en Manila, sino en casi todas las provincias, sobre todo en Negros Oriental y Occidental, en Capiz, Surigao y Cagayán-Isabela (78). La mayoría de los usuarios habituales eran varones, siendo toda-

(74) J. B. Devins, An Obeserver in the Philippines. Boston: American Tract Society. 1905, pág. 138; Taylor, obra citada, pág. 32.

(75) La cifra conservadora habla de 200.000 filipinos muertos en esa guerra. En 1900, tras menos de un año de hostilidades, un oficial del departamento de guerra reconocía 14.643 muertos y 3.297 heridos entre los filipinos (véase $L$. WolfF. Little Brown Brother: How the United States Purchased and Pacified the Philippine Island at the Century's Turn. Nueva York: Dubleday, 1961, pág. 306). Una relación tan extraña en cualquier confrontación bélica - cinco muertos por cada herido - apunta claramente al tipo de "pacificación" que se llevó a cabo en Filipinas.

(76) POMEROY [7], págs. 89 y 93-96.

(77) Devins [74], pág. 138.

(78) CPHC. [69], pág. 49. 
vía raros los casos en que las mujeres fumasen opio, aunque ya había zonas donde "el vicio se había apoderado de familias enteras", como en el pueblo de Tayasan, en Negros Oriental donde, según una fuente local, el 25 por ciento de los habitantes eran adictos (79).

A esa expansión del uso del fármaco contribuyó la dislocación social y económica vivida en el archipiélago durante la guerra, que incluyó con frecuencia tácticas de tierra quemada, torturas $\mathrm{y}$ atrocidades sistemáticas para aterrorizar a la población $\mathrm{y}$, en alganas provincias, la reclusión de toda la población indígena en "reservas» selladas por el ejército americano. La guerra destruyó totalmente la agricultura de varias provincias donde hubo que importar masivas cantidades de arroz (80). Todo ello unido a la desaparición del control gubernamental (el uso de opio ya no estaba formalmente prohibido para los filipinos) hizo que la venta y consumo de esa droga se disparase entre la población nativa. A este respecto sabemos, por ejemplo, que en 1903 había en Manila 190 tiendas que dispensaban opio (81). La mala salud, al igual que en China, Java y el sur de los Estados Unidos tras la Guerra Civil (82), contribuyó también a la expansión del uso de la droga. Decisiva en este sentido fue la epidemia de cólera que azotó el archipiélago en 1902. El poder astringente del opio lo hizo, como en tantas otras ocasiones, el mejor alivio contra la enfermedad, y muchos filipinos comenzaron a tomarlo no sólo para combatir sus síntomas, sino para prevenirlos (83). Alarmantes noticias -éstas mantenidas en secreto- apuntaban también a la extensión del uso de opio entre las tropas norteamericanas estacionadas en el archipiélago. Por ejemplo, George A. Zeller, un médico de Illinois que sirvió tres años en las Filipinas, relataba:

En los puestos aislados que mantenemos en las provincias las tiendas o almacenes de los chinos son lugares donde nuestros soldados gustan de congregarse. Cada lugar de estos tenía un fumadero de opio y el dueño se acostaba en su catre de bambú y se daba a fumar, usando sus pipas en presencia de los visitan-

(79) Idem, págs. 49 y 129.

(80) Los americanos aplicaron en Filipinas algunas de las tácticas empleadas en Estados Unidos contra los nativos norteamericanos, sioux, cheyenes, etc. Es evidente que las atrocidades cometidas por los americanos en Filipinas no dejaron nada que envidiar a las cometidas por los españoles en Cuba y que habían servido de motivo propagandístico para declarar la guerra a España.

(81) TAYLOR [5], pág. 32.

(82) Rush [19], págs. 33-35; Cour'Twricih' [6], pág. 49.

(83) Musto [3], pág. 26. 
tes con total despreocupación; quizá en el catre vecino al suyo, otro chino yacía en total estupor. Los soldados comenzaron a sentirse interesados y a probarlu. Así se ha llegado a una situación en la que probablemente unos tres soldados americanos por companía se habituaron al opio. He tratado bastantes de esos casos en los hospitales de campaña a lo largo de mi estancia (Carta de Zeller a Wright, sept. 1908) (84).

El problema pudo afectar, por lo tanto, a un 3 por ciento de las tropas americanas. Teniendo en cuenta que en la guerra se emplearon hasta 125.000 soldados norteamericanos (85), es bastante probable que varios miles de ellos retornasen a casa habituados al opio. Este punto parece confirmarse por los informes de la Asociación Farmaceútica Americana de 1903 y 1904, que apuntaban a un considerable incremento del número de soldados y marinos americanos que usaban opio tras la guerra de Filipinas (86). En éste como en muchos otros aspectos, esa guerra fue un claro antecedente de futuras aventuras diplomáticas y militares americanas en Asia, especialmente de la guerra del Vietnam.

\section{El PROYECTO TAFT Y REACCIONES}

El gobierno americano se encontró de repente con un problema sin precedentes ante el que, dado el estatus colonial de Filipinas, las opciones eran mucho más amplias que las hasta entonces tomadas en Estados Unidos (87). En tal tesitura, Taft decidió instaurar sin demora un nuevo régimen de control de la venta y consumo de opio que seguía en sus líneas maestras al modelo español (88). En junio de 1903, el gobierno civil redactó un proyecto de ley que prohibía la venta de opio a todos los residentes en las islas excepto a los individuos de "total sangre china mayores de ventiún años», quienes podrían consumirlo en

(84) El informe de Zeller fue silenciado en los debates en el Congreso norteamericano (COURWRIGHT [6], pág. 202.

(85) POMEROY [70], pág. 88.

(86) Terry y Pellens [6], págs. 23-24.

(87) Musto [3], pág. 26.

(88) Una propuesta semejante había sido hecha en 1899 por el Delegado de Hacienda americano en Filipinas, con argumentos que prefiguran los de la Comisión Filipina cuatro años después. El Secretario del Tesoro en Washington rechazó la propuesta, argumentando que tal sistema de recaudación era "ajeno a nuestro sistema impositivo". Se decidió entonces seguir adelante con la tarifa establecida que consideraba al opio "un legítimo artículo de comercio" TAYI.OR [5], págs. 3233. 
sus domicilios, manteniéndose, por tanto, la prohibición de los fumaderos públicos (89). Esa ley reinstauraba el monopolio del opio mediante contratas trienales por las que sólo podrían pujar empresarios chinos. La importación y preparación del opio quedaría confinada exclusivamente al área de Manila. Los ingresos que el gobierno obtuviese con el monopolio se dedicarían a la «inmensa tarea de la educación pública» (90). El proyecto era pragmático; pretendía frenar la expansión del uso de opio entre los filipinos y el crecimiento del contrabando en las islas.

Es importante reseñar que, a diferencia de los españoles, que preferían que se hiciera uso público de la droga, los americanos sólo toleraban el uso privado. El uso de opio en lugar público se castigaba con una importante multa. Aunque existían obvios motivos para no desear el espéctaculo de los fumaderos y los "tirados" opiómanos en el modelo de sociedad que las Filipinas querían ofrecer, resulta también evidente que esa diferencia entre la aplicación del mismo sistema por parte de españoles y norteamericanos reflejaba sustanciales diferencias respecto a la ebriedad en ambas culturas (91).

La legislación propuesta por Taft, sin embargo, encontró una intensa oposición que sorprendió al gobierno civil.

Casi inmediatamente se alzó un coro de protestas entre varios residentes en Filipinas, que pronto encontraron eco en América. Como nuevo poder imperial, los Estados Unidos, tanto por razones domésticas como internacionales, deseaba evitar la acusación de copiar el ejemplo de los "pérfidos Británicos» en fijar el hábito del opio en un pueblo dependiente (92).

En esa oposición destacó sobre todo el clero protestante destinado en las islas, encabezado por Homer Stuntz, obispo metodista y presidente de la Unión Evangélica, y Charles Brent, obispo de las misiones episcopalianas. En contacto con sus iglesias en China y en Estados Unidos, ambos fueron capaces de movilizar rápidamente un clamor contra el proyecto; miles de cartas y telegramas

(89) CPHC. [69], pág. 3.

(90) TAYlor [5], pág. 34. No olvidemos que esa educación o re-educación debía llevarse a cabo en una lengua desconocida para toda la población filipina.

(91) Ver, por ejemplo, W. MADSEN, The American Alcoholic: The NatureNurture Controversy in Alcohol Research Therapy. Springfield, III: Thomas, 1974, págs. 104-108.

(92) Taylor [5], pág. 34. 
llovieron sobre Washington, forzando al Secretario de Guerra Root a paralizar su promulgación.

Para comprender la celeridad y la influencia de esa oposición conviene recordar que los religiosos americanos llevaban décadas luchando contra el opio en China, y que "quizá en ninguna otra parte del mundo tuvieron los misioneros americanos tanta influencia en la política oficial de los Estados Unidos como en China... y en ningún otro tema ejercieron los misioneros mayor influencia en la opinión pública y en la política oficial como en la cuestión del opion. Hasta tal punto que la campaña internacional contra el comercio de esa sustancia puede ser descrita sin exageración como uun movimiento misionero $-\mathrm{o}$, mejor aún-, como diplomacia misionera (93).

Los opositores al proyecto Taft, por lo tanto, sabían que contaban con el apoyo de una considerable influencia política, que veía el problema como la promoción de un vicio entre razas degradadas a las que se pretendía rehabilitar y que empalmaba con el cada vez más poderoso movimiento prohibicionista del alcohol en la metrópoli. "Tras la Unión Evangélica», escribía Stuntz, "hay en los Estados Unidos un electorado de no menos de treinta millones... que se opone inalterablemente al principio fundamental de este decreto y a todos sus detalles. Si esos electores fueran derrotados hoy, volverían a empezar la agitación mañana con celo redoblado... por el rechazo de una legislación que sus representantes no han sido capaces de impedir» (94).

La amenaza política estaba clara. Las protestas «alcanzaron tal volumen, que para desvanecer cualquier noción de que el gobierno de Washington apoyaba el proyecto... se llegó a considerar la publicación de la correspondencia entre el Secretario de Guerra y Taft, que demostraban como tanto el presidente Roosevelt como Root habían expresado grandes reservas contra el proyecto desde el principio" (95). Mientras en Washington crecía el movimiento de protesta contra el proyecto, en Manila, la Comisión procedió a debatirlo públicamente. Por un lado, Taft y los miembros de la Comisión Filipina apoyaban la legislación propuesta; por otro, diversos sectores encabezados por Brent y Stuntz se oponían al proyecto.

(93) Idem, págs. 29-30.

(94) Devins [74], pág. 140.

(95) TAllor [5], págs. 35-36. 


\section{El DEBATE: USO Y ABUSO DEL OPIO}

Este encontronazo político en Filipinas tendría escasa relevancia histórica si no se hubieran manifestado allí con claridad dos visiones del consumo de opiáceos y de las drogas psicoactivas en general, que prefiguran las posturas de los sucesivos debates internacionales sobre su prohibición, lo que da a ese viejo debate una interesante actualidad.

Por una parte, los reverendos Brent y Stuntz no admitian que pudiera darse un uso moderado, no adictivo o, en términos morales, «no vicioso» de esa droga. Por el contrario, para ellos el consumo opio representaba "fácilmente el vicio más mortífero conocido por la raza humana" (96). Además, si era inmoral por principio que un gobierno se lucrase de los vicios de sus ciudadanos, ese lucro era intolerable cuando se basaba en el consumo de una droga esclavizante como el opio. Los demás argumentos eran derivados o secundarios respecto a esas dos premisas fundamentales. Por ejemplo, era indecente y ridículo prohibir el uso de opio a los filipinos, mientras se permitía usarlo a los chinos. El proyecto era "mala política y mala moral» y continuaba el depravado ejemplo de los británicos en su trato a los chinos. Además, los contratistas tenían un interés particular en que aumentase el número de usuarios, por lo que, una vez en control del monopolio, se esforzarían por ganar nuevos adictos (97).

Taft discrepaba de las opiniones de sus distinguidos oponentes y trató públicamente de rebatir sus razones (98). El líder de la Comisión Filipina argumentó, primero, que el comercio y uso de opio había aumentado en las islas durante la ocupación americana y que el decreto era prohibitivo, como deseaban los opositores, para siete millones de filipinos, mientras toleraba con restricciones su uso entre unos cien mil chinos, menos del dos por ciento de la población. Su objetivo era limitado, pero pragmático; esto es, quería impedir que el fumar opio se extendiera entre aquellos que no solían hacerlo, permitiendo a los chinos mantener sus costumbres. Lo contrario era discriminatorio: ¿por qué no podían los chinos seguir fumando opio si los americanos bebían alcohol a su antojo?

(96) Devins [74], pág. 140; subrayado, nuestro.

(97) TAlL.OR [5], pág. 35.

(98) Taft respetaba mucho a Brent, con quien habia viajado a Filipinas en 1902. Sus relaciones con Stuntz, una figura más fanática y lenguaraz, eran menos cordiales. 
En segundo lugar, Taft admitía que él y sus oponentes tenían puntos de vista diametralmente opuestos respecto a la naturaleza del consumo de opio. El consideraba posible e incluso frecuente el uso moderado de la droga, como el que muchos americanos hacian del café, del tabaco o del té. Reconocía, sin embargo, que el problema fundamental no estaba en Filipinas, sino en Estados Unidos, donde

el público, tal como hoy se le presenta el uso de opio, no es capaz de hacer distinciones... y percibe el fumar opio... como un vicio que no puede condenarse bastante. El público se ha acostumbrado a asociar el uso de opio, por moderado que sea, con esas imágenes depravadas de los horribles fumaderos en los que las victimas aparecen caidas en un estado de estupor y ebriedad desesperados. El público cree que no puede hacerse un uso de esa droga que no conduzca rápida y ciertamente a la destrucción del alma y del cuerpo. Pero esa opinión pública no conoce los hechos... No conoce la diferencia entre el uso de opio por parte de los chinos y el mucho más vicioso y pernicioso uso de esa droga por otras gentes. Cree, como cree el obispo Brent, que el uso de opio no presenta absolutamente ninguna forma que no sea viciosa (99).

Taft apuntó además, que, desde el punto de vista práctico, su juicio se fundaba en el éxito del sistema español, que había operado en las islas durante décadas y que había conseguido regular el uso de opio entre los chinos mientras prevenía su extensión entre los filipinos. Por eso, continuó el futuro presidente del Tribunal Supremo, toda la población nativa estaba a favor de esa medida (100).

La Comisión, siguió Taft, defendía el sistema de contratas precisamente porque incidía en temas esenciales de la competencia del gobierno civil del archipiélago. La prohibición no sólo haría crecer el contrabando y el uso de opio entre filipinos, sino que haría crecer la corrupcion en la policía y el servicio de aduanas, que se enfrentaban ya a enormes tentaciones, dada la atmósfera comercial que existía en Oriente. Le dolía por eso que se comparase la legislación propuesta con la de Gran Bretaña, pues para la Comisión que él encabezaba los ingresos del mono-

(99) Devins [74], pág. 143; énfasis nuestro.

(100) La mayor parte de los argumentos de Taft se encuentran en sus cartas y memorias al Secretario de Guerra Root escritas en junio y julio de 1903, TAYLOR [5], págs. 32-37; Devins [74], págs. 138-45. 
polio eran sólo un medio incidental para limitar el abuso de la droga, mientras para los británicos los ingresos del representaban un aspecto fundamental de su presencia en India y en China.

Los argumentos de Taft no convencieron a la oposición, que trató de rebatirlos. Stuntz afirmó que los chinos eran los primeros en oponerse a la vuelta al sistema español, y para demostrarlo, en unos días la Unión Evangélica recogió en Manila siete mil fumas de chinos que se oponían al proyecto. Los chinos se oponían, según Stuntz, porque el monopolio traería consigo un incremento del consumo, lo que supondría «ni más ni menos que la degradación de la comunidad china» (101). Taft no quedó muy convencido, apuntando que era imposible verificar la identidad de los firmantes, ya que que entre las firmas aparecían numerosas repeticiones, así como el nombre de un general chino fallecido trescientos años antes. Además, varios de los chinos que habían recogido firmas tenían intereses en la importación de opio.

Stuntz replicó bastante enfurecido que le resultaba penoso que un hombre del talante del gobernador «tan amable e imparcial ordinariamente en sus argumentos» usase una estratagema semejante. ¿Cuántos Smith o Browns o Jones había en América? ¿Cuántos eran los americanos que llevaban orgullosos el nombre de George Washington? Los que tenían intereses en el negocio del opio no eran más que cinco dentro de un total de doscientos chinos que colaboraban en la campaña contra el opio. El obispo metodista estaba seguro de que la oposición al proyecto representaba el "sólido buen sentido de la masa de los chinos de Manila" y se quejaba de la "locura de otorgar las delicadas cuestiones de la administración asiática a líderes inexpertos» (102).

La postura de los chinos merece especial atención, pues la legislación propuesta les afectaba directamente y ellos eran, además, los únicos que mantenían aún intereses en el comercio de opio. Es cierto que un gran número de chinos se manifestaron contrarios al proyecto de legalización. Precisamente, la primera protesta contra el proyecto fue la del cónsul general chino en Manila, quien se quejó en nombre de los comerciantes de opio, cuyo negocio amenazaba el monopolio. Posteriormente un grupo de comerciantes chinos llegó a contratar a un abogado norteamericano para que les representase en la lucha contra el proyecto. En su testimonio frente a la Comisión Filipina ese abogado «ad-

(101) H. Stuntz, The Philippines and the Far East. New York: Eaton and Maines, 1904, pág. 227.

(102) Idem, págs. 278-80. 
mitió que sus clientes... preferían la prohibición al sistema de contratas, porque la prohibición podia ser burlada con más facilidadb (103).

Los chinos en ese momento se encontraban en Filipinas en una delicada posición política, vistos con creciente desconfianza tanto por nativos como por americanos. Por una parte, durante la ocupación americana habían consolidado su posición económica (104), convirtiéndose en los proveedores casi exclusivos de la población nativa y acumulando un capital tan considerable que «quizá no sea una exageración afirmar que los principales beneficiarios financieros de la revolución fueron los chinos» (105). Esto no hizo sino extremar el antagonismo de la población filipina contra ellos.

De otro lado, los americanos pretendían terminar con la inmigración de chinos a Filipinas, por lo que extendieron al archipielago las leyes promulgadas al respecto en Estados Unidos y, a pesar de la violenta campaña de protesta china que llegó a boicotear los productos americanos en todo Oriente desde Singapore a Pekin, el congreso mantuvo esa medida en las sucesivas "Chinese Exclusion Acts» de 1903 y 1904 (106). Entre ambas tendencias hostiles a su presencia, cada vez menos necesaria, los chinos debían extremar su cautela en un tema tan delicado como el del opio. Manifestarse a favor de esa costumbre podía alienarles aún más de la mayoría filipina y de la norteamericana.

\section{El COMité DE LA COMISIÓN FILIPINA}

Taft y sus colaboradores no continuaron la defensa del proyecto, cuya suerte veían depender de una «opinión pública norteamericana... que contemplaba, en muchos casos críticamente, como los Estados Unidos llevaban a cabo su primer experimento de dominio colonial» (107). Pero antes de ceder al clamor prohibicionista, Taft sugirió el nombramiento de un comité que investigara el estatus legal del opio en otros países de Extremo Oriente y propusiera una

(103) TAlLoR [5], págs. 37-36; énfasis nuestro.

(104) TAN [1], pág. 8.

(105) Hasta 1898 los chinos fueron fianciados mayoritariamente por firmas americanas e inglesas. Su papel en la importación de arroz durante la guerra, sin embargo, les permitió autofinanciarse por primera vez. En el período de dominio norteamericano encontramos, por lo tanto, un creciente sector de capitalistas chinos independientes. LeGarda, obra citada, pág. 14.

(106) TAN [1], págs. 97-99.

(107) TAll.oR [5], pág. 39. 
solución al problema en Filipinas. Como decisión salomónica, tanto Root como Roosevelt apoyaron esa propuesta. Formaron parte del comité el mayor Carter, cirujano del ejército americano, el doctor José Albert, prestigioso médico filipino y el reverendo Brent, que actuó como secretario. Desde Manila, los miembros del comité visitaron Japón, Formosa, China, Java, Indochina y Singapore haciendo acopio de datos sobre el terreno y estudiando la situación del opio. A su regreso a Manila, redactaron un informe que enviaron al Secretario de Guerra en Washington.

Ese informe del comité filipino es un documento claro, directo y relevante; se trata del primer estudio comparativo sobre el consumo del opio en Oriente y la relación de tal consumo con la legislación imperante en cada país. Su influencia fue enorme. En China se tradujo enseguida al mandarín y circuló por todo el imperio, sirviendo de texto programático del movimiento antiopio (108). En el informe se aprecia muy clara la mano de Brent. Brent había sido nombrado obispo episcopaliano de Filipinas tras diez años como rector en una parroquia pobre de Boston. Era un hombre de amplios conocimientos y profunda espiritualidad, pero también de arraigados prejuicios nacionalistas y raciales, a quien no le cabía duda que en Filipinas había sido "en beneficio de esta raza que trajéramos la presión de nuestra nacionalidad sobre la decadente nacionalidad que prevalecía antes de la ocupación americana y no totalmente extinta todavias (109).

Brent sentía que el Comité había contribuido a la solución de «uno de los más graves, sino el más grave de los problemas morales del oriente» (110) y consiguió que su informe sirviera de base para tratar el tema de la prohibición del opio desde una perspectiva internacional. Desde el principio, el misionero episcopaliano había sido consciente que el caso de Filipinas ofrecía la oportunidad de abrir una nueva era en la legislación internacional sobre el opio y supo aprovechar la ocasión. Sus conclusiones animaron las futuras reuniones internacionales de Shangai y la Haya, en las que él fue uno de los principales artífices (111).

\subsection{Definiciones: uso, abuso y dependencia}

En muchos aspectos, el informe del comité filipino anticipa futuros documentos internacionales sobre drogas psicoactivas.

(108) Idem, págs. 21-25.

(109) C. H. BRENT, Prisoners of Hope and Other Sermons. New York: Longmans, Green, and Co., 1915, pág. 259.

(110) CPHC, [69], pág. 20.

(111) Musto, obra citada, págs. 35-36 y 50. 
Especialmente relevante es su esfuerzo por analizar y delimitar conceptos claves como los de uso, abuso y dependencia.

Respecto al opio el comité concluía que el uso del opio es un "vicio", porque se transforma siempre en un esclavizante hábito. Es decir, el opio es adictivo y «un hombre que usa habitualmente incluso una pequeña cantidad de opio deviene tan absolutamente dependiente de la droga como si la usase en exceso, y se convierte en un ser miserable, desesperado e inútil cuando se le priva de su dosis usual» (112). El riesgo de la adicción disuelve las barreras entre uso y abuso, pues todo uso es peligroso. La adicción, para el comité, no es un criterio extraño, impuesto sobre la experiencia de los usuarios por "expertos», sino algo que ellos mismos perciben con claridad, un criterio emic. La adicción es "esa demanda vital que el opio imprime en el fumador y que en Filipinas es conocida como guiann; un fenómeno cuyos síntomas son empíricamente constatables y pueden apreciarse independientemente de cualquier interpretación psicológica o cultural: Hay niños recién nacidos de madres que fuman opio y que necesitan inhalar ese humo para volver a la vida" (113).

Además de sufrir frecuentes intoxicaciones a causa de la droga, el usuario de opio suele necesitar aumentar gradualmente su dosis y padece de crisis de abstinencia que le hacen «incapaz e inútil para el trabajo cuando se le priva de su dosis, sea esta grande o pequeñan. El usuario vive poseído por esa compulsión «más imperiosa que el hambre» que le lleva a cometer "crímenes contra sí mismo o contra aquellos dependientes de él, más que contra el público» (114).

Están ahí los elementos esenciales de la futuras definiciones de dependencia y adicción que se elaborarían durante el siglo: tolerancia, compulsión, síndrome de abstinencia y pérdida de control sobre el consumo de la substancia a pesar de la disfuncionalidad laboral, familiar o social que tal consumo produce. En ese sentido, el del comité filipino es un texto eminentemente "moderno", que anticipa futuras conclusiones de las organizaciones de expertos -incluidas varias de la Organización Mundial de la Salud- en sus esfuerzos por establecer definiciones "operativas» y culturalmente neutrales de conceptos intrínsecamente am-

(112) CPHC. [69], pág. 31.

(113) Idem, pág. 49.

(114) Idem, pág. 49. 
biguos y etnocéntricos (115). Se parece a la mayoría de ellos en la capacidad para ignorar la enorme variabilidad personal, la multiplicidad de excepciones apuntadas por muchos de los expertos consultados, la importancia de factores extrafarmacológicos en el efecto de las drogas psicoactivas y por los saltos de las realidades médicas a las morales y políticas (116).

Se diferencia de ellas, sin embargo, en que sus autores no se sentían aún obligados a neutralizar o enmascarar el trasfondo político-moral del problema, ni los conflictos socioeconómicos, raciales, étnicos o generacionales que subyacían a su problematización del uso de psicofármacos. Así, la expansión del opio en Filipinas se contempla como especialmente preocupante porque el filipino "es un individuo con un grado relativamente bajo de vitalidad... (que) sufre palpablemente de los avances de un vicio como éste más que aquellos a quienes la naturaleza ha dotado de poderes de resistencia». Además,

Cuando se comparan los efectos de fumar opio en gentes de distinta constitución y temperamento racial, es un mal argumento el mantener que en algunos casos no se alcanza una profunda degradación y que, por lo tanto, no se alcanza un serio mal... La degradación, como la pobreza, es relativa. De manera que si un chino, por ejemplo, dotado de intensa energía y elevadas dotes intelectuales rebaja esos poderes en un diez por ciento debido a algún vicio, no llega, sin embargo, a incapacitarse por su exceso y sigue siendo tan capaz como el malayo con menores dotes a quien el vicio reduce su vitalidad en la misma medida, pero con ello le hace tocar el fondo de su capacidad tornándole inutil (117).

\subsection{El rechazo del uso moderado}

El comité, sin embargo, tuvo ocasión de comprobar que mucha gente consideraba el uso de opio no dañino y que «un largo número de chinos lo usan tan moderadamente como nos-

(115) El documento anticipa también la medicalización del fenómeno en otro aspecto: la visión epidemiología del uso de drogas, en la que se destacan los factores "médicos" sobre los de transmisión de innovaciones sociales. Así, se cita a un "experto" que apaunta que la costumbre del uso de opio "se transmite por contagio más que por imitación", aunque los mecanismos apuntados son todos culturales: "presión de grupo", "prestigio" y "consumo conspicuo" - deseo demostrar que uno puede gastar tanto como los demás, etc. (CPHC, obra citada. pág. 141).

(116) N. E. Zinberc;, Drug. Set. and Setting. New Haven: Yale University Press, 1984, págs. 25-45.

(117) CPHC. [69], págs. 47-48. 
otros usamos el té o el café»; había incluso distritos donde la costumbre dominante era la de ufumar opio sólo en los días de mercado"; mucha gente, por tanto, parecía hacer un uso controlado, es decir, no adictivo del opio. A pesar de eso, el comité rechazó la tesis de que uun uso moderado del opio no tiene efecto injurioso y sólo el exceso es dañino». Al contrario, "el uso de opio es un mal que ninguna ganancia monetaria puede compensar y la voluntad americana no permitirá a sus ciudadanos el animarlo ni siquiera pasivamente" (118).

Se trataba de un ejemplo de reduccionismo que se justificaba moralmente en nombre del bién común, pero que se tomaba realmente en virtud de la fuerza de los intereses implicados en el tema del opio. Así, si comparamos el informe de la comisión filipina con el de la nombrada por el parlamento británico diez años antes, vemos que, a pesar de su parcialidad, el informe del comité filipino es más equilibrado y efectivo que el mastodóntico de la comisión británica que investigó la oportunidad de suprimir el comercio de opio entre India y China, examinó 723 testigos, llenó 2.500 páginas de memorias, anexos y testimonios y acabó produciendo un documento "pálido" y "poco convincente» (119).

El contraste entre ambas comisiones ilustra cómo las fuerzas hegemónicas en ambos países defendían constelaciones de intereses diferentes. El gobierno británico de la India, a diferencia del americano en Filipinas, tenía decisivos intereses comerciales en la producción bengalí de opio y fue capaz de inclinar la balanza hacia la innacción y la permisividad.

Es evidente que la China decimonónica ofrece el mejor campo de estudio para conocer los peligros reales y ficticios del consumo masivo de opiáceos, así como las ventajas e inconvenientes de las estrategias prohibicionistas y liberalizadoras. La distinta lectura de la situación china que hacen ambas comisiones es, por lo tanto, paradigmática. Por un lado, los británicos, como los españoles, llegaron a convencerse de que el uso de opio entre los chinos no era injurioso para la mayoría de la población, llegando, en ocasiones, a ser beneficioso:

El uso de opio con moderación se lee en el informe de la comisión británica «no es perjudicial y la moderación es la regla», citando a un experto, que en realidad, había calificado su respuesta afirmando que entre los usuarios chinos «quizá un

(118) Idem, págs. $21,34,126$ respectivamente.

(119) Owen [10], pág. 320. 
treinta por ciento usen opio sin causarse ningún daño, un cuarenta por ciento con leve perjuicio y un treinta por ciento con considerable perjuicio (120).

Los mismos datos eran leídos por los norteamericanos de forma diametralmente opuesta; a nivel social era evidente la imposibilidad de un uso no destructivo del opio. Mientras el informe británico concluía resaltando la futilidad de tratar de suprimir un hábito tradicionalmente establecido, el norteamericano apuntaba la necesidad de tomar medidas de inmediato. Dos formas de ver el papel en el mundo del poder estatal y dos formas muy distintas de entender la expansión imperial que nacían, por otra parte, en países culturalmente tan próximos.

\subsection{Los regimenes coloniales de control del opio en Asia}

De acuerdo con su percepción del uso y el usuario de opio, el comité admiraba sobre todo el método seguido por los japoneses. Japón tenía una legislación totalmente "prohibitiva y efectiva" seguida «al pie de la letra por una población de 47 millones, de los cuales 8.000 son chinos», con el resultado de que «los chinos residentes en Japón son, en su mayor parte, no fumadores». Los japoneses habían tenido éxito no porque desconocieran las propiedades del opio sino porque la ley japonesa "no es un mandato sobreimpuesto al pueblo por Ia voluntad de autoridades despóticas: ni el fruto de la victoria de la mayoría sobre una minoría, como es el caso en varios de los estados norteamericanos donde aparecen prohibiciones de licor en sus estatutos, sino opinión pública cristalizada. El pueblo no sólo obedece la ley, sino que está orgulloso de ella; no la alteraría aunque pudiera hacerlo... y como no hay demanda, no hay estímulo a la importación fraudulenta y no hay contrabando, ni tráfico ilíciton (121).

El comité había percibido con claridad qué hacía de la japonesa una legislación efectiva. No está tan claro, sin embargo, que el modelo japonés fuera fácilmente aplicable a otros países de Oriente. Porque no había sido la ley la que había producido el rechazo japonés del opio, sino al contrario: la ley era efectiva porque en Japón imperaba un odio tal hacia esa droga que «un usuario de opio en Japón sería socialmente como un leproso. Un

(120) Idem, pág. 326.

(121) CPHC. [69], págs. 21, 22, 23; subrayado nuestro. 
japonés puede emborracharse cada noche sin perder casta, pero ¡ay de él si cayese en las seducciones del opio!» (122). El caso de Formosa era, en este sentido, un experimento decisivo. Allí, los japoneses habían impuesto una legislación distinta a la de todos los otros poderes coloniales de Asia.

Japón, "una nación no cristiana, es el único país visitado por el comité, donde la cuestión del opio es enfocada desde su punto de vista únicamente moral y social» (123). Los europeos, por el contrario, en todas sus posesiones en oriente habían preferido tratar el opio como un problema fiscal y no moral (124). Las leyes europeas en este sentido "no pretenden ser leyes para proteger al pueblo de un vicio, sino regulaciones comerciales que defienden una rama del comercion (125).

Dado que su propósito declarado en Filipinas era el de educar y civilizar a la población nativa y no el de explotarla, los americanos se sentían en este tema más cercanos a los japoneses que a los viejos poderes europeos. Por eso la política preferida del comité era la practicada por los japoneses en su posesión de Formosa, arrebatada a China tras la guerra en 1895. Allí los japoneses estaban llevando a cabo una "política humana" de "progresiva y no categórica prohibición» que perseguía la total desaparición del uso de opio tras unos años de mantenimiento a aquellos usuarios que obtuvieran una licencia gubernamental (126). En Formosa los japoneses eran una minoría empeñada en la rehabilitación de la mayoría, mediante una "cura moral» que, según el comité, buscaba basarse en el ejemplo. Así, en las escuelas públicas se hacía hincapié en los males que causaba el opio, y "como los niños japoneses y los formosanos se [sentaban] juntos en las mismas aulas, es fácil percibir cómo la virtud de los primeros se imprimirá sobre los últimos» (127). De hecho, seguía el comité, el sistema aplicado en Formosa estaba ya produciendo

(122) Idem, pág. 22.

(123) Idem, pág. 24.

(124) Los holandeses, en Java; los ingleses, en Singapur y Malasia; los franceses, en Indochina y los españoles en Filipinas toleraron e incluso promovieron el uso de opio entre algunos grupos étnicos. Los sistemas en las colonias europeas iban del estricto monopolio gubernamental, como en la Cochinchina francesa y Java, donde el gobierno importaba, manufacturaba y distribuía la droga al por mayor, hasta un sistema de contratas muy parecido al español, como el que imperaba en los "Strait Settlements", bajo administración británica.

(125) CPHC. [69], pág. 49.

(126) Idem, pág. 26.

(127) Idem, pág. 27. 
resultados muy satisfactorios, aunque de pasada se afirmaba también que el contrabando continuaba en varias regiones (128).

\subsection{Recomendaciones y resultados}

De acuerdo con sus conclusiones y siguiendo el modelo japonés, el comité recomendó para Filipinas un régimen de progresiva prohibición del opio, que se iniciaría estableciendo un monopolio gubernamental sobre la importación y venta de la droga por un período de tres años, a partir del cual se prohibiría totalmente el comercio de esa droga en el archipiélago, excepto para usos médicos. Durante esos tres años se proporcionaría opio en limitadas cantidades sólo a aquellos varones adultos que fueran usuarios crónicos y que obtuvieran una licencia del gobierno. No se harían a este respecto distinciones entre los diversos grupos étnicos. De la distribución de la droga se encargarían funcionarios del gobierno.

Paralelamente, debía iniciarse una campaña «educativa y correctiva" que previniese a los niños y jóvenes contra los peligros del opio y ofreciese tratamiento gratuito a todos los usuarios que deseasen «liberarse del vicio». Los filipinos habituados al opio deberían ser privados del derecho al voto e inhabilitaclos para el desempeño de cargos públicos (129). El comité consideró también las penas a imponer por consumo de opio a partir de la prohibición, que irían desde una multa la primera vez, hasta penas de prisión y pérdida del derecho de voto para los nativos y deportación para los chinos. Se sugería también que se mantuviera el acta de exclusión respecto a los chinos, lo que limitaría la contaminación desde el continente (130).

Las dos bandos en conflicto aceptaron las conclusiones del comité: a Stuntz le parecieron «satisfactorias para las fuerzas protestantes" (131) y Taft, ya Secretario de guerra en Washington, retiró definitivamente el proyecto de contratas y elevó el informe al Congreso. En marzo de 1905, la alta cámara convirtió en ley las principales recomendaciones del Comité de la Comisión Filipina. Por consiguiente, se prohibiría el uso y comercio de opio en Filipinas tras un plazo transitorio de tres años. Durante esos tres

(128) Idem, pág. 27.

(129) Idem, pág. 51.

(130) Idem, págs. 3 y 55.

(131) Devins [74], pág. 144. 
años, los adictos chinos podían obtener una licencia para proveerse legalmente de opio que habrían de consumir en sus casas. Los importadores y los vendedores al detall habrían de pagar elevadas tarifas y someter sus transacciones a un estricto control gubernamental. A los filipinos se les prohibía el uso de opio, excepto por prescripción médica. Aunque, el sistema no era del todo el propuesto por los misioneros, sin embargo, estos transigieron, considerando el corto tiempo que restaba para la prohibición total.

El gobierno civil ofreció tratamiento gratuito a todos aquellos adictos que quisieran curarse. Para sorpresa de los funcionarios, tras un año de espera, sólo se presentaron diez solicitudes para curarse de la opiomanía en todo el archipiélago (132). Por otra parte, aunque se calculaban por lo menos 20.000 usuarios chinos de opio, tan sólo se solicitaron unas 12.700 licencias, por lo que se entendió que muchos usuarios habían dejado de consumir o se abastecían de opio fraudulentamente.

\section{LA PROHIBICIÓN}

Al acercarse la fecha en que entraría en vigor la prohibición, sus partidarios estimaban muy optimistas que un 40 por ciento de los usuarios de opio en el archipiélago habían ya dejado de usar la droga y que muchos otros habían moderado su uso (133). Sin embargo, cuando el 1 de marzo de 1908 el opio se convirtió en sustancia prohibida en Filipinas, una avalancha de adictos acudió en busca de ayuda a los hospitales y consultorios médicos, que se vieron pronto saturados. Los tratamientos of recidos eran inapropiados e incluso degradantes y muchos familiares y amigos de los pacientes se quejaron airadamente. Por ejemplo, el pabellón instalado en el hospital de Cebú hubo de cerrar cuarenta y dos días después de abrirse debido al rechazo y boicot de los pacien-

(132) Musto [3], pág. 261. Los japoneses en Formosa experimentaron un fiasco semejante, cuando en 1929 of recieron tratamiento gratuito a todos los opiómanos no registrados y se encontraron que, de unos 25.000 usuarios que se calculaba existían en la isla, sólo treinta acudieron a tratarse (Informe a la Liga de Naciones del Comité de Investigación sobre el Control del Opio en Extremo Oriente, Ginebra, 1930, pág. 420). El sistema japonés en Formosa no tuvo, por lo tanto, el éxito que pronosticaba el comité de la Comisión Filipina. Los japoneses, por cierto, usaron posteriormente el opio de forma bastante siniestra en su ocupación de Manchuria.

(133) TAILOR [5], pág. 44. 
tes al tratamiento ofrecido. La administración americana no se había preparado adecuadamente para la emergencia (134).

Los datos respecto al uso de opio en las islas en los años sucesivos son escasos y contradictorios. De acuerdo con las fuentes oficiales, el resultado de la prohibición fue muy positivo. Brent informó del gran éxito de la experiencia filipina en la reunión de Shangai. El número de adictos, según las autoridades, había disminuido, no rebasando en 1911 los cinco mil entre los chinos, habiéndose reducido entre los filipinos al 4 por ciento de los que había antes de la prohibición (135).

Dado el carácter clandestino del comportamiento que trataban de medir, es difícil conocer hoy la fiabilidad de tales estimaciones. Hay bastantes datos que muestran que la prohibición del comercio de opio se aplicó con rigor, a pesar de lo cual el contrabando continuó. Un caso en este sentido ocurrió en enero de 1909, cuando el ingeniero jefe y el segundo a bordo del barco mercante inglés Rubi fueron arrestados, arrojados en una "celda asquerosa" y procesados al encontrarse en las bodegas del barco "sesenta onzas» de opio. El incidente estuvo a punto de causar un conflicto diplomático, pues el juez americano encargado del caso amenazó a todos los capitanes británicos que fondeasen en Filipinas con una importante multa si a partir de entonces se encontraba opio en sus barcos. Los británicos se habían comprometido en la reunión de Shangai a no tolerar la importación ilegal de opio a Filipinas, pero la puesta en práctica de tal compromiso resultaba muy difícil. Como alegó en su queja al Ministerio de Exteriores británico la asociación de la marina mercante inglesa, tal compromiso ponía en peligro el comercio entre Hong Kong y las islas, pues "no hay un barco que llegue al puerto de Manila en la que no haya chinos en la tripulación que no fumen opio» (136).

En las siguientes décadas los datos muestran la misma pauta divergente: funcionarios norteamericanos que minimizaban la seriedad del problema del opio, mientras fuentes independientes discrepaban más o menos con esas estimaciones (137). Por ejemplo, H. L. May, representante americano en el consejo del opio de la Liga de Naciones, visitó Filipinas en 1926 y encontró que el opio de bajo precio era fácilmente asequible en las islas, siendo

(134) ZaRCo [7], pág. 103.

(135) TAYLOR [5], págs. 43-45.

(136) D. Wet:ks, Rolfe without Frederick. Edinburgh: The Tragara Press, 1983, págs. 5-18.

(137) TAYLoR [5], págs. 44-45. 
frecuente la corrupción entre la policía en ese tema y no demasiado estricta la aplicación de la ley (138).

Unos años después, en 1929, el comité de la asamblea de Ginebra visitó Oriente para recabar información sobre la situación del opio y pasó dos semanas en Filipinas. Los americanos temían que el comité fuera muy crítico con el sistema prohibicionista, dado que sus miembros - ninguno de los cuales era norteamericano- se inclinaban por un método de control basado en la provisión legal de opio a los «adictos confirmados». Sin embargo, el comité europeo señaló que la política prohibicionista en Filipinas había tenido cierto éxito en reducir la "extensión del vicio», que sin embargo seguía «siendo un problema considerable, sobre todo porque el sistema aplicado no había podido erradicar el contrabando* (139). Esos datos del comité internacional fueron confirmados al poco tiempo por la investigación de la señora Wright, que pasó tres meses en Filipinas en 1930. Según su informe, en Filipinas seguía consumiéndose una gran cantidad de opio, que entraba de contrabando y resultaba fácilmente asequible (140).

Incluso en 1959, cincuenta años después de la prohibición, todavía quedaban en el archipiélago consumidores de opio de la vieja generación que se hacían con la droga en el mercado negro. Aunque su número era seguramente inferior al que hubiera habido de no instaurarse la prohibición, las condiciones comerciales y legales en que usaban opio lo hacian más caro, más adulterado y más peligroso (141). Donde había cambiado radicalmente la situación era en el continente chino, que ya no era una fuente de fumadores ni de droga para el archipiélago.

\section{CONCLUSIONES}

Nuestra breve visita histórica ha puesto de manifiesto como muchos de los problemas que confrontamos hoy en torno a las drogas ilegales tienen un largo pasado; contrariamente a lo que algunos - siempre prestos a opinar sin documentarse- suponen alegremente, la figura social del adicto y los problemas colectivos

(138) Musto [5], págs. 262, n² 22.

(139) Report of The International Commission, citado en Taylor [5], pág. 44.

(140) TAYLOR [5], págs. 273-74.

(141) R. M. ZaRCO, "A Short History of Narcotic Drug Addiction in the Philippines, 1521-1958"' en Historical Bulletin of Pilipinas. Marzo, 1959, vol. III, $\mathrm{n}^{\mathrm{o}}$ 4 págs. $86-100$. 
derivados de la adicción no son creaciones de la sociedad de consumo; su existencia es ya patente cuando menos en la China imperial y en las Filipinas del siglo pasado.

De la misma forma, el problema de si la legalización es una respuesta socialmente más justa y razonable al problema que plantea el uso masivo de opiáceos (las drogas que provocan el modelo clásico de adicción) es algo que discuten ya misioneros americanos a principio de siglo y antes que ellos, eruditos chinos en 1836, cuando era evidente que una considerable parte de los males que se achacaban a "la droga» se debían a su régimen legal y no a su farmacología (142). Es decir, hay un gran elemento de repetición cíclica y de "deja vu» en la mayoría de las crisis de drogas contemporáneas.

En este sentido, puede ser ilustrativo conocer cómo una administración española impuso un sistema de mantenimiento de opio que resultó más sencillo que ninguna de sus alternativas y que funcionó con eficacia en relación con los objetivos perseguidos. El sistema no se nutría de la tolerancia hacia la minoría china ni del respeto por sus costumbres. Su base fue eminentemente fiscal y de orden público: el opio se prestaba adecuadamente al objeto de tasar a esa minoría que se contemplaba sobre todo como mano de obra y "materia imponible» y reducía el gasto que hubiera exigido la persecución del contrabando en un archipiélago de siete mil islas. La cesión de la gestión del monopolio a contratistas privados, por otra parte, representaba un considerable ahorro en burocracia estatal.

Es decir, el sistema español soslayaba muchas cuestiones morales y políticas. Esto, no lo olvidemos, resultaba relativamente fácil, ya que el uso legal de opio sólo concernía a una minoría rechazada y estigmatizada, y la administración no tenía que preocuparse del tratamiento o rehabilitación de aquellos usuarios a quienes el exceso causara problemas médicos, laborales o legales: siempre podía deportar al infortunado, que desaparecía así del cuidado del gobierno filipino. La administración española adoptó una postura pragmática, discriminatoria y cómoda.

El sistema español no se basaba tampoco en una visión tolerante del consumo de opio, lo que se aprecia en la taxativa prohibición impuesta a los filipinos. También aquí el sistema parece haber surtido efecto, evitando la captación de nuevos consumidores entre los grupos étnicos donde no existía tal costumbre.

(142) OWEN [10]. 
El régimen de control del opio en Filipinas demuestra, a la vez, paradójicamente, como tanto la legalización como la prohibición pueden "funcionar», es decir, limitar el daño derivado del uso masivo de sustancias psicoactivas en una sociedad determinada.

Pero lo esencial en el caso filipino es que no existió demanda entre los nativos. A pesar de los cambios sociales derivados del crecimiento económico y del ascenso del nacionalismo, los filipinos no llegaron a interesarse por el opio. Era "cosa de chinos» y los filipinos tenían otros intereses. Parece, por lo tanto, que en el tema de las drogas la mejor política es la que se apoya en la costumbre social, no la que trata de imponerla; las normas legales, tolerantes o no, funcionan mejor cuando trabajan a favor y no en contra del control social informal.

También conviene señalar, sin embargo, que la prohibición de drogas puede funcionar en una sociedad cerrada, autoritaria y represiva, capaz de imponer un sistema de control social exhaustivo y homogeneizante. Así, la crisis del opio en China se cerró tras la toma del poder por los comunistas en 1949, quienes en unos años erradicaron allí el consumo masivo de opio tras casi dos siglos de infructuosos esfuerzos (143).

De otro lado, si bien el caso de Filipinas demuestra que la prohibición de ciertas drogas ha sido generalmente fruto de la intransigencia, el fanatismo y el enmascarado deseo de controlar a minorías que se perciben como amenazantes, conviene también señalar que, allí donde ha existido, la permisividad de costumbres ajenas en el uso de drogas no ha sido fruto de la tolerancia, sino del interés político y económico.

Los españoles, como los británicos, llegaron a convencerse de que entre los chinos era muy frecuente el uso moderado o controlado del opio y que ni siquiera la adicción era un serio problema social entre la población china siempre que el fármaco se mantuviera accesible. Al contrario, la provisión de opio podía representar una lucrativa empresa para el Estado. En consecuencia, optaron por tratar al opio como un objeto más de comercio, es decir, mediante la ley civil y no la penal.

En el caso americano, por el contrario, ganaron las fuerzas que veían el opio como un mal irredimible, rechazaban toda transigencia con su uso y se horrorizaban con que el Estado pudiera lucrarse de su comercio. Aún a sabiendas de que la

(143) J. D. SPEnCE, The Search for Modern China. New York: W. W. Norton and Co. 1990, pág. 518. 
mayoría de los chinos usaba el opio moderadamente, como otros usan el alcohol, el tabaco o el café y que en muchos casos era motivo de solaz y consuelo que ayudaba al trabajo, los "expertos» norteamericanos prefirieron enfatizar que el uso masivo del fármaco producía - lo que también era cierto- un gran número de usuarios no moderados que se dañaban a sí mismos y a sus familias.

Se impuso así una visión fundamentalista, que prejuzgaba la existencia de una solución que había de ser, necesariamente, "la más humana de las soluciones» (144) y para llevarla a cabo se convocó una "cruzada» famarcológica en toda regla (145).

Había en esa actitud un claro etnocentrismo, un sentido de superioridad cultural que asumía que la mejora moral del mundo coincidiría necesariamente con los intereses religiosos, políticos y económicos de la potencia imperial en ascenso.

La postura respecto al opio no era diferente de la que muchos otros norteamericanos sostenían respecto al alcohol y el movimiento anti-opio se fundió y se apoyó con frecuencia en el movimiento abstencionista. Es importante comprender cómo entre los norteamericanos ha predominado un objetivo utópico que no es el de limitar el daño social que causan los fármacos psicoactivos, sino el de «liberar» por completo a la sociedad de todo uso no terapeútico de esas sustancias. Aunque de claro raigambre puritano, esa tendencia absolutista rebasa los límites del puritanismo, siendo quizá una expresión paradigmática de la modernidad y sus injustificadas ilusiones.

Entre los norteamericanos venció la convicción de que un santo horror a "la droga" protegía mejor a la colectividad, siendo, por lo tanto, conveniente para la salud pública promoverlo, aunque tal horror se fundamentase en verdades a medias, en la ignorancia de hechos notorios, en la ritualización del error, y, en el caso de los chinos y el opio, de una opinión pública dominada por el etnocentrismo y el racismo.

Se estableció así una de las características más importantes de la relación de nuestro siglo con las drogas ilegales: el prestar mucha atención al fármaco y poca al modo en que se usa, con frecuencia el factor clave en el daño que causa. En consecuencia, se ha tendido menos a desarrollar controles y sanciones informa-

(144) CPHC. [69], pág. 21.

(145) B. D. Johnson, "Righteousness before Revenue: The Forgotten Moral Crusade Against the Indo-Chinese Opium Trade". en Journal of Drug Issues vol. 4. 1975; Escohotado [56], pág. 225. 
les que moderen el uso que a erradicarlo por completo. Este absolutismo, a la larga, ha resultado contraproducente; entre otros motivos, porque la prohibición inhibe precisamente a los usuarios potencialmente más aptos para desarrollar controles, sanciones y rituales de protección (146) y, en suma, una cultura más "positiva» o benigna del uso de la droga que limite su impacto social (147).

Si es un objetivo legítimo del poder político el limitar entre los ciudadanos el uso perjudicial de drogas, ¿cuál es el mejor método para conseguirlo? Es evidente que la mejor forma de reducir el "abuso" de drogas -especialmente en una sociedad democrática- es mediante la costumbre y el control social informal, sin la imposición coercitiva del Estado (148).

De hecho, el afán prohíbicionista, tanto en Filipinas como en Estados Unidos, es un esfuerzo por imponer el control social formal donde el control informal había fallado, donde diversos grupos veían el uso de drogas de forma contrapuesta. Había en él una nostalgia por el pasado, por una homogeneidad moral y cultural que no existía ya en ninguno de los dos países.

El final del caso del opio en Filipinas es el principio de un nuevo paradigma en la relación política con el uso de drogas. La revolución copernicana que supuso la prohibición nos ha colocado ya en otro universo, generando poderosos factores económicos, institucionales y simbólicos con los que hay necesariamente que contar en cualquier opción futura, pues la relación del Estado y la colectividad con las drogas ilegales está urgentemente necesitada de una profunda revisión. En ella, el cuidadoso examen del pasado será esencial, si no queremos repetir sus errores, ampliados ya a nivel planetario.

Ahora que los españoles hemos sufrido en propia piel una crisis de drogas, conviene que miremos atrás para mirar hacia adelante. Este estudio pretende apoyar ese esfuerzo recuperando un ejemplo de nuestra propia historia olvidada: el pasado colonial español en Filipinas.

(146) ZiNBERG [116], pág. 5.

(147) E. Lamo DE EsPinOSA. "Por una cultura positiva de las drogas" en Drogalcohol VIII (3). 1983.

(148) El caso del tabaco en Estados Unidos, una droga todavía subvencionada por el gobierno y la única en la que se aprecia a largo plazo una disminución masiva de su "abuso", apunta en esa dirección. En relación al tabaco, las leyes han seguido y no precedido a los cambios en las costumbres colectivas. 